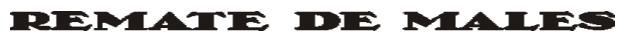

Campinas-SP, v.38, n.2, pp. 631-682, jul./dez. 2018

\title{
SituAÇÃo de VALÉRY TRAdUZido No BRASil
}

\author{
Álvaro Faleiros ${ }^{1}$ \\ Roberto Zular ${ }^{2}$
}

Resumo: Este artigo trata das traduções de Paul Valéry (1971-1945) publicadas em livro no Brasil desde a década de 1930, buscando um diálogo entre os projetos tradutórios e a literatura comparada, tendo como eixo a noção de historicidade. (inclui tradução do poema "A Pítia", ao final do artigo).

Palavras-chave: Valéry; tradução; historicidade.

\section{SITUAÇÃO DE BAUDELAIRE, SITUAÇÃO DE VALÉRY}

Em 1924, Paul Valéry faz uma importante conferência em Mônaco intitulada "Situação de Baudelaire". Nessa conferência, queanos mais tarde João Alexandre Barbosa escolheria como texto inicial de sua antologia dos ensaios de Variedades, a palavra "situação" revela-se como a possibilidade de explorar a complexidade da obra de arte tomada como ato: as condições materiais de produção e a situação de enunciação produzida na e pela linguagem; o processo e a obra; a voz e a escrita; os tempos históricos heterogêneos que se cruzam no poema e na leitura; uma política do pensamento como tradução generalizada, enfim, as questões de Estado da poesia, a vaidade e a verdade da busca por uma voz, a incompreensão e a glória. Baudelaire, como Valéry, é um clássico, não apenas porque traz um crítico em si mesmo, mas porque essa crítica explode as múltiplas

1 Professor do Departamento de Letras Modernas da Faculdade de Filosofia, Letras e Ciências Humanas (FFLCH) - USP: <faleiros.usp@gmail.com>.

2 Professor do Departamento de Teoria Literária e Literatura Comparada da Faculdade de Filosofia, Letras e Ciências Humanas (FFLCH) - USP: <rzular@usp.br>. 
dimensões em jogo no ato artístico e não se deixa seduzir pelos "ismos" que reduzem a arte a apenas um ou dois de seus parâmetros construtivos.

No caso de Baudelaire e sua "modernidade, moderninade", diria Meschonnic, tratava-se ainda, segundo Valéry, de "situar-se" no coração do romantismo francês: uma necessidade pessoal profunda de diferenciar-se e, sobretudo, não deixar a voz do romantismo identificar-se unicamente com a voz de Vitor Hugo, mas trazer outras camadas de sentido que perturbam a homogeneidade histórica do movimento, atravessá-lo por uma ação refletida, por materiais mais complexos, mesmo que para isso tenham de "perder em intensidade aparente, em abundância, em movimento oratório, o que eles ganharam em profundidade, em verdade, em qualidade técnica e intelectual" (OE, p. 604).3

Esse "romantismo" implicava outra dimensão histórica, ligando Baudelaire ao teor crítico do primeiro romantismo alemão que ressoava, via Colleridge, em Edgar Allan Poe:

Há nos melhores versos de Baudelaire uma combinação de carne e espírito, uma mistura de solenidade, calor e amargura, de eternidade e intimidade, uma aliança raríssima de vontade com harmonia, que os distingue claramente tanto dos versos românticos como dos versos parnasianos. (OE, p. 610)

A situação de Valéry no momento de escrita da conferência não deixa de ter relação com aquela de Baudelaire. As vanguardas dominam a cena literária, e Valéry havia recusado ser o "patrono" do surrealismo depois de anos de relação com André Breton. Ao lado dessa ebulição vanguardista, havia também a questão da "poesia pura" e a emergência dessa grande linhagem moderna, cujos pontos de partida e de chegada, na França, são precisamente Baudelaire e Valéry. Segundo William Marx (2002, p. 69):

[...] grosso modo, a doutrina aceita hoje em dia na história da literatura é aquela que foi duplamente confirmada, dos dois lados do Atlântico, por dois autores-chave, Edmund Wilson e seu O castelo de Axel, em 1931, depois, em 1933, De Baudelaire ao Surrealismo, por Michel Raymond. Para Wilson e para Raymond, que tiveram o mérito de fornecer as primeiras interpretações coerentes do modernismo literário, Baudelaire se situa inegavelmente no ponto de partida de uma linhagem poética que passa por Mallarmé e o simbolismo e não conduz a ninguém menos que Eliot e Valéry.

3 As referências para Oeuvres complètes de Paul Valéry serão dadas com "OE" e o número de página. 
Essa leitura de Valéry, que afinal estava paradoxalmente no auge da glória como Baudelaire, se teve o mérito de estabelecer uma linha de intelegibilidade crucial para a crítica dita formalista, ao mesmo tempo obliterou a complexidade da obra e da relação de Valéry com a história e com a história literária. Como notou no calor da hora um atento Sérgio Buarque de Holanda (1996, p. 188):

\begin{abstract}
[...] as diferenças entre os críticos a respeito de Valéry são de molde a deixar os leitores na maior das perplexidades. A poesia toda contenção (e não formismo como é fácil supor) do artista de Charmes e de La jeune parque não desaprova apesar de tudo uma constante colaboração do leitor. E é por isso que cada qual a cria à sua imagem. Houve quem descobrisse um Valéry escolástico, outro, o sr. Daniel Halévy, conseguiu construir um Valéry hegeliano, o sr. Thibaudet, um Valéry bergsonista e finalmente Lucien Fabre, que constata essas divergências, vê um Valéry positivista!
\end{abstract}

Talvez seja interessante perceber que a obra de Valéry é um pouco de tudo isso, mas sobretudo um espaço de tensão entre as infinitas maneiras de se estar em um poema, tensionando a relação entre processo e obra e, como bem notou Sergio Buarque de Holanda, mantendo uma forte contenção entre essas instâncias, a qual, mais do que um "formismo", instaura o signo linguístico na sua equivocidade, isto é, na (co-)incidência tensa de mais de um modo de significação que deixa para os leitores uma verdadeira abertura de sentido. A forma-formante, tomada aqui como hiato entre o processo e a obra, é a construção de um limiar ético que demanda novos atos a partir daqueles que o poema delineia.

Não se trata, portanto, como mostra William Marx no artigo citado acima, apenas de uma síntese feliz entre uma métrica rigorosa que agradaria à crítica tradicionalista e um hermetismo mallarmeano que permitiria a adesão dos mais jovens, mas sim, da construção do poema como um limiar entre a voz que existe e a voz que vem e deve vir. Nesse atravessamento de vozes heterogêneas, no mínimo entre as vozes e pontos de vista internalizados na fatura do poema e sua recepção, cria-se uma diferença de potencial que transforma o poema em uma partilha de vozes - onde se joga toda a política, a questão de Estado de que falávamos -, o poema como uma partitura em que o máximo de capacidades e afecções são acionadas. Como rastro do movimento da passagem do corpo em ato (carne e espírito), o poema aciona corpos e produz singularidades, eis que, como dito a respeito de Baudelaire, "o próprio daquilo que é realmente geral é a sua fecundidade” (OE, p. 612). 
Assim, se Baudelaire e Valéry podem ser postos em relação é pela fecundidade que esse atrito produz, e não por uma linha evolutiva e exclusiva que oblitera outros caminhos da modernidade. Esse atrito fecundo vem, para dizer o mínimo, da própria tensão que em poucas linhas nos trouxe até aqui: desde o contexto imediato de Baudelaire, passando pela historicidade e o ritmo - acionando uma outra dimensão temporal e outros espaços de relação via Poe - para produzir uma historicidade da poesia francesa como se Baudelaire fosse uma espécie de "big bang" produzido "après coup" por Rimbaud, Verlaine e Mallarmé (que o criam como precursor), para chegarmos ao ensaio (e à obra!) do próprio Valéry.

Eis alguns fios da malha complexa da recepção de um poeta-crítico com o alcance de Valéry. Mas para sairmos da falsa dicotomia que, por um lado, leva de Baudelaire a Valéry e, por outro, mostra como Valéry produz os seus precursores, aqui também o que há é a implicação recíproca desses dois movimentos, isto é, a co-incidência de mais de uma historicidade que marca a modernidade de Valéry.

Se nos voltarmos para os poemas de Valéry de Feitiços, como aponta Marx (2002, p. 870), veremos como essas diferentes temporalidades produzem uma "poesia de vocação ontológica". É o modo de existência do poema e da linguagem que aí se coloca em jogo. Para Marx, teríamos um verso que traria o gesto hermético e a opacidade de Mallarmé colocados lado a lado com um fundo temático neo-clássico. Mas, por outro lado, não é difícil ver uma inversão forma-fundo na qual um verso radicalmente anacrônico de extração clássica repropõe uma contemporaneidade avassaladora para a sobrevivência dos mitos. Nessa inversão o neo-clássico se coloca como uma atualização contínua que dá espessura histórica a questões modernas, como também faria Freud, que escapam ao imediatismo da vida no capitalismo avançado.

Não se trata, portanto, de um neoclassicismo, como uma retomada de temas clássicos, mas da instauração de um outro regime de temporalidade que atravessa os espaços de experiência dados, criando novos horizontes de expectativas pela singularidade de sua relação com o passado como duração e reminiscência. Como as Ninfas de Aby Warburg, retomadas por Didi-Hubermann (2013), as imagens clássicas (que já eram sobrevivências) que Valéry re-encena mostram o quanto elas sobrevivem, o quanto elas estão presentes na sua aparente ausência, o quanto o modo de sobrevivência das imagens no poema nos coloca diante de uma imagem 
que é sempre mais do que ela e que é atravessada por outras imagens, por outros tempos, ritmos-imagens, daquilo de que elas são imagem.

Trata-se de um espaço metafórico intervalar que é também um intervalo entre duas metáforas, a mostrar esse lugar - eis a situação - de quase-existência, esse virtual que se cria entre o ato e suas ressonâncias, as temporalidades que as imagens carregam. A hesitação prolongada é esse espaço intervalar de atravessamento de um ato por mais de uma determinação (a sonoridade e a sintaxe, por exemplo), da história por mais de uma historicidade, de uma imagem pelos fluxos heterogêneos que fazem dela imagem.

Se a poesia é essa hesitação prolongada entre som e sentido, ritmo e imagem, o verso, para Valéry, torna-se um espaço de regulação dessa relação. Nem um verso parnasiano que tem a métrica e a rima como um princípio hierárquico, nem um verso "livre" modernista que tem na posição soberana do escritor o crivo do que conta como verso. $\mathrm{O}$ verso funciona aqui como uma "correlação regular", um plano de consistência que mantém uma relação tensa entre todos os parâmetros compositivos sem permitir que nenhum deles (nem o próprio verso) se torne o único princípio hierárquico (e, por isso, do nosso ponto de vista, Valéry não é um "formalista").

Como mostram os manuscritos de Feitiços apresentados por Florence de Lussy (1990-1996), o verso se mantém como espécie de atrator da multiplicidade infinita que se dá na escrita de um poema. Os afetos (e, mais, a variação entre os afetos), os outros textos, as questões de poética, as imagens, as metáforas, os desdobramentos do pensamento, as relações, os cálculos, as contingências, o acaso... O verso é aí um espaço de correlação entre o que veio e o que está por vir, como a rima - reforço do verso - que para Valéry importava menos pelas palavras que aproxima do que pela espera que instaura. São muitas as diferenças qualitativas em jogo, e o processo caminha para um refinamento quase infinito da passagem de uma qualidade a outra, de um plano a outro. Da ideia à semântica, do afeto à linguagem, do desenho à letra, do ritmo à imagem.

$\mathrm{O}$ anacronismo deliberado de Valéry encontra aqui uma insuspeitada vocação ontológica: vocação, pelo outro modo de ser da voz, e ontológica porque, eivado de voz, o signo carrega outros modos de existência que, como queria Valéry e admirava Benjamim (1994), coloca em xeque os ideais de progresso, de prazer imediato, de um futuro sempre presentificado, do culto ao novo. Esses ideais "modernos" solapam em um tempo-espaço 
homogêneo todas as tensões e crises de temporalidades e dos regimes de imaginação que só o paciente trabalho com o heterogêneo pode propiciar. O silencioso trabalho que permite a transformação das margens em rumor.

\section{HISTÓRIA, LINGUAGEM}

Essas variações ontológicas, atravessando a historicidade (tanto da história quanto da linguagem) e a possibilidade de se inscrever uma outra linguagem na linguagem, como uma outra história na história, não são para Valéry meras "questões de linguagem”, mas a linguagem colocando em questão a ética e a política que levaram a Europa a uma guerra fratricida. A situação de Valéry nesse momento está permeada pela Guerra, a qual, por sua vez, está fortemente ligada à "crise do espírito", aos erros dos países europeus quanto à história e à política do pensamento. Valéry é dos primeiros defensores de uma comunidade europeia e, ao mesmo tempo, ambiguamente, alguém que sempre desconfiou da capacidade da política de manter a paz, que não é mais "que uma guerra que admite atos de amor e de criação no seu processo: ela é então algo mais complexo e mais obscuro que a guerra propriamente dita, como a vida é mais obscura e profunda que a morte" (OE, I, 994).

Nesse ponto, vemos o quanto Carlos Drummond de Andrade tocou em uma funda ferida quando, na epígrafe de Claro enigma, acionava Valéry para afirmar: "os fatos me entediam”. É que os fatos, continua Valéry, "são a espuma das coisas e o que me interessa é o mar". Os fatos são para Valéry uma simples convenção, enquanto a história é atravessada por um campo de forças que cabe ao poeta, sem alarde, evitando tanto os grandes acontecimentos como os versos excepcionais, colocar em funcionamento na máquina pulsante do poema (Cf. OLIVEIRA; SOUZA, 2016).

A história em sua "longue durée" diriam os membros da Escola dos Anais, atravessada pela história literária e pelo funcionamento heterogêneo da linguagem. Essa encruzilhada reaparece anos mais tarde em um crítico aparentemente tão anti-valeriano, mas que, no fundo, é dos que mais reverbera as questões de fundo de Valéry. Trata-se de Henri Meschonnic, o qual, sobretudo em seu livro póstumo Linguagem, história, mesma teoria, adota o que ele chama de uma "perspectiva semântica da história” (DESSONS, 2012, p. 14). Essa perspectiva acompanha Valéry desde a juventude, quando publicou, em 1898, um ensaio sobre a "Ciência das significações” de Michel Bréal (apud BARBOSA, 1991). Se ligarmos esse viés semântico da visada linguística de Valéry como algo que não é dado, 
mas sempre por fazer, não fica difícil perceber que esse é o mesmo viés que o leva à crítica da noção de fato, desconfiando de sua existência como algo dado e evidente. Ao contrário, Valéry ressoa em Meschonnic (2012, p. 11) quando este afirma que "o sentido na história deve ser construído" e que a história "muda o sentido".

Essa implicação recíproca entre linguagem e história atravessada pela aventura da significação, parte fundamental da aventura humana, coloca mais uma vez a questão da equivocidade, no sentido de ser impossível determinar um sentido único para a história e para a linguagem postas em funcionamento. "Linguagem, história, são um problema de sentido porque tudo dá e toma sentido. O sentido não é um haver. O sentido é um fazer, um tomar, um dar. Um ato sempre infinito de interação, de reescritura" (MESCHONNIC, 2012, p. 26).

Isso significa que ambas não têm um sentido pré-determinado, mas se constituem de muitas camadas de determinação, como a poética, a ética, os regimes de imaginação, os regimes de historicidade etc. Como vimos a respeito do verso em Valéry, essas determinações recíprocas, passando por zonas de indeterminação, se ressignificam mutuamente. Se admitimos que o sentido é equívoco, atravessado por mais de uma voz, por mais de um sentido, o problema da significação é o modo como produzimos relações entre essas redes de possibilidades.

Por isso a experiência da linguagem se confunde com a história, pois ambas estão pautadas na historicidade que "é uma relação... o encontro indefinidamente renovado do histórico e do a-histórico, dos passados e dos presentes do sentido" (MESCHONNIC, 2012, p. 72). É por isso também que sempre "há duas historicidades: uma que é a inscrição nas condições de produção de sentido, outra que, mesmo estando situada, não cessa de sair e de ficar ativa no presente..." (p. 56). Vemos como a questão da história mais uma vez aciona o complexo enunciativo da "situação" sua historicidade que é ao mesmo tempo dada e construída - entre as condições de produção e o espaço de reinvenção de toda enunciação. ${ }^{4}$

4 Esse modo de relação e a historicidade que ele produz é sempre atravessado por regimes de historicidade específicos, isto é, o modo como a experimentamos e transformamos a relação entre o passado e o futuro, ou como propõe Koseleck, o espaço de experiência e o horizonte de expectativa. Como mostrou Lucius Provase (2016), a história e todos os regimes de enunciação (sejam eles verbais ou não) produzem essa relação entre experiência e expectativa. O modo como se dá essa relação, na esteira de Hartog, Provase chama de regimes de historicidade que, se por um lado são dados e determinados, por outro, como vimos com Meschonnic, sempre pode transformar essa relação, como vimos, por sua vez, com o próprio Valéry. 
A história e todos os regimes de enunciação (sejam eles verbais ou não) produzem essa relação entre experiência e expectativa que, se por um lado é dada historicamente, por outro, como vimos com Meschonnic, sempre pode transformar essa relação, por sua vez, com o próprio Valéry.

Em um espectro ainda mais amplo, que reverbera a antropologia histórica da linguagem de Meschonnic, Bruno Latour (2006, p. 67) afirma que

[...] a antropologia está lá para nos mostrar que a passagem do tempo pode ser interpretada de diferentes formas, como ciclos ou decadência, como queda ou instabilidade, como retorno ou presença contínua. Chama-se temporalidade a interpretação dessa passagem, de modo a distingui-la claramente do tempo.

Desse modo, também Latour nos ajuda a compreender que não se trata de totalidades sistemáticas que perfazem blocos históricos homogêneos, mas de espaços de sobredeterminação produzindo conjuntos de "reorganizações heterogêneas" (LATOUR, 2006, p. 72).

\section{HISTÓRIA, LINGUAGEM, TRADUÇÃO}

Procuramos delinear até aqui o sentido dessa "situação" de Valéry e, sobretudo, o que está em jogo nela: uma sobredeterminação que toma a história e a linguagem como variações, e a possibilidade ao mesmo tempo determinada e indeterminada de produzir regimes de imaginação e regimes de historicidades que atravessam a crise de versos e a crise do espírito, assim como as implicações recíprocas entre estética, ética e política. Entramos assim em uma temporalidade de outra ordem, feita das diversas temporalidades ligadas à dupla historicidade de que fala Meschonnic.

Esse atravessamento de tempos e imagens - essa historicidade que permeia nossos modos de existência - torna-se particularmente pregnante quando ela se materializa nas práticas tradutórias. Isso porque, aquilo que fica em latência no jogo entre tempos diferentes - o diferimento, diria Derrida - na tradução vem à tona pela inescapável co-incidência de línguas, de espaços de experiência, de regimes de historicidade, enfim de tudo que dizemos aqui da situação, sempre dupla, queatravessa um projeto de escritura e um projeto tradutório. Essa tradutibilidade para Valéry tem a ver, como para Saussure, com as qualidades sensíveis heterogêneas e a passagem de um sistema a outro de sensibilidade e pensamento, como se o próprio pensamento fosse uma tradução generalizada. Traduzir: 
situar-se entre discursos, experiências sensíveis, mundos heterogêneos. Por isso afirma Meshonnic (2012, p. 43) que a linguagem tem a ver com "a tradução, equivalente aproximado de uma experiência que concerne ao discurso, talvez mais do que às línguas".

Se tomamos a experiência da linguagem como ato, vemos que ela se dá sempre como uma prática, e as práticas, por sua vez, se situam no interior de um sistema de relações. Isto é, a linguagem é um espaço de relação entre experiências sensíveis, uma prática que se relaciona com outras práticas, atravessada por mais de uma historicidade. O que ocorre na prática tradutória é o cruzamento dessa situação com ainda uma outra, a da situação do tradutor que implica, por sua vez, um espaço de relações sensíveis e historicidades. Assim, se a própria linguagem é feita de cruzamentos que se articulam, na prática tradutória isso se materializa com um outro sistema de relações, de comparações e de práticas que evidenciam esse cruzamento de historicidades.

Por isso, se intensificarmos os limites, a historicidade e a tradução se confundem, o que se evidencia no conceito de retradução, se o lermos como um processo contínuo de transformação das situações e projetos tradutórios. Assim, mesmo que não se trate da retradução de um mesmo texto, os próprios modos de traduzir têm a sua historicidade e se configuram de maneiras diversas em um constante diálogo, seja na relação com a cultura de partida, seja com as questões internas da cultura de chegada.

A tradução não se dá como um sistema de diferenças produzido internamente na língua de chegada, mas como uma diferença entre sistemas postos em ato pela atividade específica e constitutiva dos sujeitos da enunciação (MESCHONNIC, 2012, p. 43). O ato tradutório se produz em um complexo enunciativo que coloca em ato a dobra entre um sistema de diferenças dado e a diferença entre sistemas. Essa dobra é tanto interna a cada sistema literário, como atravessada pela diferença entre sistemas linguísticos que a tradução projeta como parte de sua prática.

Desse modo, a tradução se confunde e põe em ato a literatura comparada. Ela é atravessada por esse duplo eixo da relação externa e interna; atravessada por suas historicidades que colocam sempre em trânsito os vestígios materiais desse espaço de transferência que se forma, não apenas pelas marcas deixadas ao longo do processo, mas também pelo campo de comparações - de relações - que se dá a ver pela presença de diferentes regimes de historicidade. É esse o desafio da tradução: não 
buscar equivalências entre as línguas, mas os processos de ressignificação que operam na comparação entre os mundos que esses campos linguísticos colocam em relação.

No caso de Valéry é interessante notar como essa dupla implicação entre literatura comparada e tradução revela muito das dinâmicas internas da literatura brasileira. De um modo geral, podemos dizer que Valéry aparece toda vez que a relação entre modernização e modernismo é colocada em xeque. Isto é, sempre que a historicidade homogênea do progresso da nação se confunde com a prática literária - por exemplo, quando o verso livre é visto como progressista, espontâneo e brasileiro, e o verso métrico como atrasado, passadista, construtivo e exógeno -, a densidade da reflexão valeriana aparece para bagunçar as dicotomias infernais de nossa experiência literária. E é em torno dessas questões propostas em um artigo de Sergio Buarque de Holanda ("O lado oposto e outros lados") que vemos uma das primeiras aparições de Valéry em uma carta de Mario de Andrade (2001, grifo nosso) a Manuel Bandeira, de 1926: "você pode falar que não gosta de Valéry, suponhamos que só por causa da influência que você sabe que ele tem na França e porque ele está perto e tomando parte na mesma luta que você ou que nós você é incapaz de dizer que ele não tem espírito moderno".

Nesse sentido - e veja-se como a historicidade é importante - uma das marcas profundas da recepção de Valéry no Brasil é esse embate entre uma recepção conservadora e ligada aos "amantes do verso e da poesia pura" e outra, totalmente problematizadora, ligada à sua recepção entre os modernistas. E, embora nossa leitura esteja muito ligada ao modernismo, o fato de essa tensão se desdobrar de maneiras diferentes na França e aqui não deixará de nos permitir tecer um horizonte fundamental para a análise que propomos das traduções de Valéry publicadas em livro no Brasil. É que essas comparações, como vimos - antes teoricamente e agora veremos situadas -, permitem tecer algumas das múltiplas redes de nossa temporalidade.

Escolhemos quatro pontos de articulação, quatro obras de Valéry traduzidas no Brasil que, pelo seu modo de existência, produzem variações entre contextos e provocam situações que revelam os regimes de historicidade a partir dos quais nós produzimos relações, elas também atravessadas pela dupla enunciação da tradução.

A primeira delas é a publicação do poema "Os passos" na antologia Poetas de França por Guilherme de Almeida em 1936, primeira publicação 
no Brasil de um poema de Valéry em livro. A segunda é o conjunto das publicações ao longo dos anos entre 1940-1980 de quatro livros dedicados exclusivamente ao Cemitério marinho, feitos por Damasceno (1949; 1960), Wanderley (1974) e Vasconcelos (1981). A terceira situação é a publicação, em 1984, de $A$ serpente e o pensar de Augusto de Campos. A última das situações é a tradução de uma seleção de textos críticos de Variedades, escolhidos e apresentados por João Alexandre Barbosa.

Se é certo que a recepção de Valéry não se resume às traduções, podemos, no entanto, considerar, como afirma William Marx (2002, p. 219) a respeito do discurso crítico de Valéry que "a tradução é um dos numerosos lugares estratégicos onde se revelam as concepções do texto próprias a um crítico", pois é "sem dúvida mais eficaz partir de uma prática crítica efetiva para voltar aos poucos aos aspectos mais teóricos, do que se apegar às tomadas de posição, ainda que brilhantes, mas não necessariamente representativas da realidade dos discursos" (p. 219). É nessa perspectiva, de distinguir linhas de força a partir de uma prática crítica efetiva - a tradução - que teceremos essas redes, sempre em diálogo com a literatura comparada.

\section{NO ENTRETANTO DOS TEMPOS}

Como vimos com Mario de Andrade, a figura de Valéry aparece quando a tentativa de homogeneizar uma certa dicção modernista é posta em questão, embora desde os anos 1920 não tenham faltado leituras que reforçavam a ideia de um poeta formalista e ligado à noção de "poesia pura”. William Marx (2002), em "Nascimento da crítica moderna”, mostra à exaustão a construção dessa mitologia valeriana, especialmente pelas novas demandas de "close reading" das universidades inglesas e americanas que o associaram a T. S. Eliot.

Nesse cruzamento de tempos, não deixa de ser curioso que a primeira publicação de um poema de Valéry em livro seja feita por Guilherme de Almeida. Afinal, trata-se de um poeta visto pela crítica tanto como alguém que "pertenceu só episodicamente à Geração de 22. Não havendo partido do espírito que a animava, também não encontrou nele pontos definitivos de referência estética" (BOSI, 1998, p. 418), quanto como "um dos mentores do modernismo brasileiro", segundo Marcelo Tapia (2010). Este autor retoma, para ilustrar seu argumento, a conferência "Revelação do Brasil pela poesia moderna” (escrita em 1925, no Rio de Janeiro), que expressava a conclusão a que Guilherme de Almeida chegara sobre a Semana de 1922: 
Poetas do Brasil, começamos a balbuciar agora o nosso ritmo brasileiro. Isto espantou, naturalmente, os que nunca souberam ser de sua terra e de seu tempo; os que, habituados a declamar, num eterno soneto constantemente emendado, o seu eterno nacionalismo, ouviram, pela primeira vez, uma ideia nova dentro da cadência nova de uma língua nova para um país novo. [Assim...] A Semana de Arte Moderna plantou, na nossa vida intelectual, um marco divisório entre o passado e a atualidade.

Para sairmos dessa alternativa infernal e entendermos a complexidade da relação de Guilherme de Almeida com o modernismo, basta ver a importância que ele atribuía a seu papel como tradutor, o que revela tanto a necessidade de relação com uma poesia não apenas nacional, como a relação com autores de outros momentos históricos - com outras organizações rítmicas e imagéticas -, que precisavam ser internalizados, via tradução, na língua portuguesa. E mais, é a primeira antologia de poesia bilíngue, tensionando o espaço entre as duas línguas, e pautada em uma estrutura cronológica não teleológica que permite muitas formas de relação entre o passado e o futuro num caminho que vai de François Villon a Paul Éluard.

Esse caminho, passando por Ronsard e Du Bellay, Paul Claudel, Mallarmé e Valéry, dá uma densidade histórica inusitada à complexa rede que forma uma literatura nacional. Daí ser relevante que o poema de Valéry escolhido por Almeida seja exatamente "Os passos"; um poema que retoma o encontro de Éros e Psiquê, recortando a cena mítica exatamente nos instantes que antecedem a aproximação que revelaria a identidade de Éros (e acabaria com o encanto e a paixão): "Retarda essa atitude terna/ser e não ser”. Como se vê, trata-se de um poema-poética, no qual a relação com o tempo, o retardamento, a espera, coloca em questão a velocidade e o progresso; o jogo de claro-escuro, presença-ausência (a equivocidade do signo), tensiona a exposição bruta; enfim, o mito se colocando contra a mitologia moderna do tempo homogêneo.

Essa escolha crítica de Guilherme de Almeida reforça a forma difícil do modernismo brasileiro, suas tensões e contradições (Cf. LUCAS, 2018), que, longe de enfraquecê-lo como um bloco homogêneo, o torna ainda mais interessante. Nesse sentido, basta ver que a questão do verso tradicional/ verso livre ganha uma dinâmica interna e uma outra concepção que não permite uma associação fácil com o progresso e a nacionalidade. Afinal, a própria escassez de traduções é indício do francês como língua franca entre os poetas, embora nem sempre saibamos o modo como a leitura 
dos poemas se dava, o que se evidencia com mais facilidade na prática tradutória.

No entanto, é fácil constatar como o projeto tradutório de Guilherme de Almeida se coaduna com a grande transformação na literatura brasileira operada na década de 1930 com "a perda de auréola do Modernismo" (CANDIDO, 2011, p. 223); um período "mais moderno que modernista" (BOSI, 1998, p. 426). E para Bosi (p. 433) essa é uma característica que marca a fase dos anos 1930 a 1950, mais universalizante, metafísica, hermética, "ecoando as principais vozes da 'poesia pura' europeia do entre-guerras: Lorca, Rilke, Valéry, Eliot, Ungaretti, Machado, Pessoa...."5

Aqui é interessante notar que, para entendermos a passagem que separa a publicação de um só poema, "Os passos", na antologia de Guilherme de Almeida ea publicação seguinte, de um livro exclusivamente dedicado ao "Cemitério marinho", faz-se necessário observar o lugar que Valéry passa a ocupar no núcleo duro do modernismo em um arco que vai de Mario de Andrade a Drummond, passando por Murilo Mendes e, sobretudo, João Cabral de Mello Neto. ${ }^{6}$ Traçaremos aqui brevemente esse percurso.

Desde a "Escrava que não é Isaura", de 1922, Mario de Andrade vinha formulando uma poética mais complexa e densa do que aquela propalada nos manifestos modernistas. Essa poética ganha corpo - e forte

5 Também para Sergio Buarque de Holanda (1996, p. 389): "Entre os nomes de autores europeus ou americanos que ao lado de Fernando Pessoa, por exemplo, ou de um Rilke, ou de um Valéry, vêm merecendo a decidida preferência das gerações ascendentes de poetas brasileiros, o de T. S. Eliot ocupa um lugar privilegiado. Essa simples preferência, ao menos no caso de Eliot, já é indício seguro de um momento novo na poesia nacional. Não se pode dizer, é certo, que os autores citados tenham sido desconhecidos das gerações anteriores. Mas o fato é que, se chegavam a interessar muito vivamente este ou aquele escritor, tratavase de fenômenos isolados, sem força para imprimir novo rumo às correntes dominantes". 6 Importante notar que a historicidade que propomos aqui é perpassada por essas leituras críticas que escolhemos, embora saibamos da importância de Valéry para os simbolistas tardios, Cecilia Meireles, Jorge de Lima e em praticamente todos os membros da Geração de 45, que ficará aqui representada, no âmbito deste artigo, por João Cabral. Para mais informações cf. John Gledson, Drummond e Valéry, em Influências e impasses: Drummond e alguns contemporâneos, Trad. Frederico Dentello, São Paulo, Cia. das Letras, 2003, pp. 140-169; Gustavo Ponciano Cunha de Oliveira e Jamesson Buarque de Souza, "Drummond e Valéry: enigmas eventuais, Itinerários, Araraquara, n. 43, jul.-dez. 2016, pp. 179-195; Douglas Silva, Recepção, apropriação e poética em "Fábula de Anfíon" de João Cabral de Melo Neto, disponível em: <www.abralic.org.br/anais/arquivos/2016_1491258380.pd>; Ricardo Gonçalves Barreto, Método e miragem: Murilo Mendes e Paulo Valery, Magma, n. 3, 1996, pp. 69-77; Roberto Zular, Valéry e o Brasil ou a literatura comparada como produção de contexto, Ponto e Vírgula, São Paulo, 2013, pp. 49-65. 
ressonância valeriana - quando os problemas do artista são atravessados por outra temporalidade mais próxima do artesanato. Chegamos aí nas especificidades dos materiais (som, cor, pedra etc.) e nas práticas que deles decorrem com força de ação e movimento. Entre o material, a configuração do objeto artístico e o ato como marca singular de uma ação "artesanal", Mario de Andrade situa sua poética num espaço da ordem do indefinível, do indecidível, da vertigem e, acrescentaríamos com Valéry, da ética e da política que atravessam a estética.

Entre o corpo do artista e os corpos que ele aciona se produz uma experiência de outra ordem, nem apenas material nem imaterial, algo como vemos em "Fábrica de Fantasmas" (ANDRADE, 1993), que Mario diz coincidir "quase textualmente com Valéry" quando este afirma: "Uma história aprofundada da literatura deveria ser encarada, não como uma história dos escritores e acidentes de suas vidas, nem mesmo como uma história de suas obras, mas exatamente como uma história do espírito naquilo em que ele produz e consome literatura" (VALÉRY apud ANDRADE, 1993, p. 71).

O amálgama que se arma aqui entre práticas e afetos, bem como entre "formas" e "tendências humanas", materialidade e técnica, corpo e espírito, "inteligência” pessoal e "condições de diversas ordens sociais" mostra o quanto a questão da história literária se faz pelos múltiplos fatores em jogo nas práticas artísticas e pelos diferentes tempos que elas articulam. Desse modo, Mario procura apontar para uma outra poética valeriana que pode, pois, ser compreendida como esse entre-lugar do artista e do artesão, entre a obra e o processo, a técnica e o gesto, entre o trabalho com a linguagem e a voz, entre a voz e a partilha de vozes que permite deslocar o impasse: "ou construímos ou... romantizamos" (ANDRADE, 2002, p. 108).

Ao escapar dessas duas águas é que o mais valeriano dos poetas do modernismo, João Cabral de Melo Neto, performará gradativamente sua poética na esteira do artista e do artesão, mais apropriadamente aqui entre o engenheiro e o bricoleur, entre "O engenheiro" e a "Pedra do sono" ou o "sonho do engenheiro" (que não produz monstros, mas poesia!). Mais do que um poeta das coisas, um poeta da negação, um poeta da construção ou um poeta da (meta)linguagem, a poética de João Cabral fortemente alimentada por Valéry é um modo singular de articulação entre todas essas "coisas". 
Se, como vimos, não há linguagem que não seja um espaço de correlação regular entre variações heterogêneas, a própria linguagem, como nossa experiência das "coisas", só se dá porque transitamos entre qualidades sensíveis e contextos que diferem. A negatividade em João Cabral seria esse lugar no qual os sistemas se cruzam, negando-se mutuamente por sua diferença, mas estabelecendo entre ambos ao mesmo tempo uma relação que permite sistematizá-los em oposições. A bricolagem entre experiências sensíveis produz, desse modo, ao mesmo tempo uma sistematização das relações por oposições internas em cada campo da experiência, sua parte de engenharia. Como sonhava Valéry, a poética de João Cabral se produz por gestos compositivos heterogêneos.

Nos poemas em que a presença de Valéry é mais explícita, esse movimento fica claro. Em "A Paul Valéry", de O engenheiro:

\author{
É o diabo no corpo \\ ou o poema \\ que me leva a cuspir \\ sobre meu não higiênico? \\ Doce tranquilidade \\ do não-fazer; paz, \\ equilíbrio perfeito \\ do apetite de menos. \\ Doce tranquilidade \\ da estátua na praça, \\ entre a carne dos homens \\ que cresce e cria. \\ Doce tranquilidade \\ do pensamento da pedra, \\ sem fuga, evaporação. \\ Febre, vertigem. \\ Doce tranquilidade \\ do homem na praia: \\ o calor evapora, \\ a areia absorve. \\ As águas dissolvem \\ os líquidos da vida. \\ E o vento dispersa \\ os sonhos, e apaga \\ a inaudível palavra \\ futura (que, apenas
}




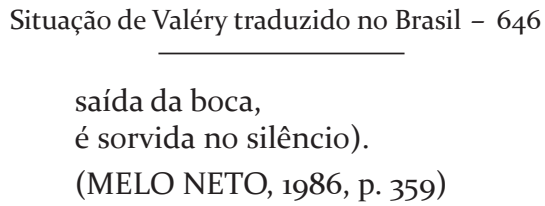

saída da boca, é sorvida no silêncio).

(MELO NETO, 1986, p. 359)

Aparentemente de forma paradoxal, é a negatividade que vem para o primeiro plano, mas "é o diabo no corpo" que leva a "cuspir" sobre o meu "não higiênico". O "não", portanto, se produz entre o diabo, o corpo, o cuspe, o "meu" e o seu caráter "higiênico".

Assim, o poema de Cabral vai acionando o "esboço de serpente" e a metafísica do não-ser que é, no fundo, a negação de uma onisciência ou de um ponto de vista absoluto como o de Deus, desdobrando-se para outras "doce(s) tranquilidade(s)", como a da estátua e do pensamento da pedra (que reverberam "as colunas") ou do "homem na praia" (muito próxima da cena de "Eupalinos", em que há o encontro com um objeto enigmático) até todas as tentativas de paralização do movimento se dissolverem nos "líquidos da vida" (em uma leitura próxima do gesto de jogar o vinho no mar, de "O vinho perdido") e se dispersarem com o vento (como na necessidade de tentar viver, do final do Cemitério marinho: "o vento se levanta... tento seguir vivo") para se projetar como palavra ao futuro embora inaudível - e ser sorvida entre a boca e o silêncio (que, afinal, é o espaço da leitura).

O não é o lugar mesmo onde as coisas deixam de ser apenas coisas para tornarem-se signos, com a condição de serem postas em relação com outras coisas e outros contextos, mesmo que aqui essa negatividade se espalhe em torno do "não-fazer", o pudor quanto ao exibicionismo narcísico dos tempos modernos. A negação, portanto, instaura relações, como ficará claro em o cão sem plumas, em que o rio, como experiência social, é visto como negação, dor e crítica da seca do nordeste, ao mesmo tempo em que se abre para um ilimitado jogo de variações metafóricas, constituídas pela espessura da falta que dá densidade e equívoco à realidade. Aquele rio que não é um rio é como um cão, por sua vez, sem plumas ${ }^{7}$ em um movimento que poderia continuar indefinidamente.

Como afirma Valéry na rubrica "Poiética" da edição Pléiade (1974), o poeta se coloca em um lugar equívoco, que tem de um lado todas as coisas e de outro, toda a linguagem; essa relação, os "mil dedos da linguagem" como no poema de Cabral sobre Ponge, produz uma ontologia plana entre o mundo e a linguagem, na qual o mundo pode funcionar como signo

7 Gesto no qual nega, ao mesmo tempo, as plumas retóricas da Geração de 45 . 
e a linguagem, como mundo material. A longa gestação desse caminho aparece claramente na reescrita do melodrama Anfion, de Valéry, na "Fábula de Anfion", de Cabral. Como mostrou Eduardo Sterzi (2009), trata-se aqui de uma encenação do deserto. Essa encenação se correlaciona com o silêncio, como ponto crítico no qual se produz uma autoridade sem governo ou uma soberania poética que se perfaz ao se desfazer: como "apetite de menos". Mas, como vimos, opera aqui uma forte relação entre deserto e fertilidade, engenharia e bricolagem: a negação como um gesto sacrificial que transforma o corpo em linguagem ou, ainda, em um deserto cultivado, como um pomar às avessas. É daí que vem a potência do ser quando pensado com sua relação com o não-ser, o nascer entre a vida e a morte, como uma relação na qual, como vimos com Valéry, a vida se faz mais profunda e opaca - espessa - do que a morte.

Essa operação que implica reciprocamente a bricolagem das coisas e das palavras e a engenharia dos sistemas de relações que daí deriva (e que se tornaria mais pregnante no decorrer da obra de Cabral para esmorecer gradativamente) faz com que os poemas articulem contextos diferentes postos em relação. No fundo, o próprio agenciamento de Valéry se dá por uma torção de contextos, pois o que sempre se evidencia é a dissonância das poéticas. João Cabral agarra literalmente o universo valeriano, ao mesmo tempo em que aponta para a diferença entre esse universo e as condições de produção em que ela opera no Brasil. Como em seu "Cemitério pernambucano de São Lourenço da Mata", no qual uma retomada do "Cemitério marinho" mostra tudo o que aquele de Pernambuco não tem, como se de cemitério não tivesse sequer o nome e fosse feito da constituição negativa e precária de sua própria existência como cemitério. ${ }^{8}$ Esse movimento, como vimos até aqui, redunda em uma torção dos contextos dos dois cemitérios - como das duas poéticas - que se equivocam como se a mesma palavra "cemitério" acionasse dois mundos diferentes postos em tensão. Essa recepção como produção de diferença se torna muito evidente também em todas as comparações de paisagens, animais, traços psicológicos, formas de falar, de dançar etc., como se a transferência cultural fosse uma produção material de estranheza que

8 "Cemitério pernambucano" (São Lourenço da Mata): "É cemitério marinho/ mas marinho de outro mar./ Foi aberto para os mortos/ que afoga o canavial.// As covas no chão parecem/ as ondas de qualquer mar,/ mesmo as de cana, lá fora,/ lambendo os muros de cal.// Pois que os carneiros de terra/ parecem ondas de mar,/ não levam nomes: urna onda/ onde se viu batizar?// Também marinho: porque/ as caídas cruzes que há/ são menos cruzes que mastros/ quando a meio naufragar". 
torna visível, dizível e mesmo pensável uma crítica à sociedade brasileira, produzindo o que Modesto Carone (1979) chamou de outra inteligência do real.

É no intervalo desse desdobramento da poética de Cabral que veremos surgir a primeira tradução em livro do "Cemitério marinho" por Darcy Damasceno. Poeta da chamada Geração de 45, traduziu o poema valeriano, reduzindo-o ao seu aspecto mais oficial, em um gesto de compreensão mais literal e organizando-o por decassílabos sem rima. Tradução esta que Sérgio Buarque de Holanda (1996, p. 105), em um artigo publicado na imprensa em 1949, chamou de "paráfrase" e associou a um "voltar para trás" e a um cuidado da forma. É importante frisar que esse recuo não deve ser necessariamente compreendido como um problema, embora a solução de Damasceno tenha questões sérias que o levariam retraduzir o poema nos anos 1960.

É interessante notar como aqui já se delineia o Valéry "formalista" e poeta da consciência (a ponto de ser traduzido literalmente). Mas ao mesmo tempo outras temporalidades vêm à tona. Por exemplo, quando o próprio Mario, em manuscrito que se encontra no Instituto de Estudos Brasileiros, salienta a respeito dessa questão que "Valéry metrifica para ficar livre", ecoando outro valeriano confesso, Otavio Paz (2009, p. 25): "a forma que se ajusta ao movimento/ não é prisão mas pele do pensamento". Por outro lado, a quadra cabralina, ao ressoar a tradição nordestina, o verso antimusical (co-incidência de uma métrica e um deslocamento do acento quase visual) e a rima toante (espaço tenso entre a consonância vocálica e a dissonância consonantal) é uma solução espantosamente interessante e tensa para os problemas da poética valeriana do verso como regulação de gestos compositivos heterogêneos. ${ }^{9}$

No meio do caminho entre o caminho de Cabral e o da tradução de Damasceno, há um outro gesto, diríamos que quase-tradutório, que para além da epígrafe configura os poemas de Claro enigma, sobretudo "A máquina do mundo" e "Relógio do rosário", como um forte diálogo com Valéry. Há aqui a retomada de uma outra cadência pautada pelo ritmo regular, que cria um plano de consistência na relação entre os versos,

9 Essa coincidência de temporalidades no verso é tratada desde o início da torção da poética valeriana por Cabral (1986, p. 336): "flor é a palavra/ flor, verso inscrito/ no verso, como as/ manhãs no tempo". Ou ainda: "Quando a flauta soou/ um tempo se desdobrou/ do tempo, como uma caixa/ de dentro de outra caixa” (p. 325). 
dando-lhes profunda espessura histórica e um importante espaço de coesão para o livro como um todo (Cf. FRANCISCO JR., 2014).

Em poucos poetas brasileiros o verso como regulação teve a força de amparar os reenvios e, sobretudo, controlar a soberania do poeta sobre a matéria. Aqui a voz e as variações subjetivas são reguladas por um conjunto de determinações heterogêneas, entre as quais o verso, que é apenas um dos elementos, evitando-se ao máximo que ele se torne um parâmetro hierárquico. Não se trata, portanto, de um formalismo, mas, como vimos com Otavio Paz, trata-se de um outro modo de existência, no qual o ritmo se torna pele e inflexiona a regra, produzindo um admirável contínuo entre os planos (sonoro, semântico, afetivo, histórico, metafísico etc.). Contínuo antieuclidiano que, ao expelir a visão da máquina do mundo, ativa a escuta atenta do mundo para se manter, mesmo cambaleante, no movimento tátil das "mãos pensas". Essa fineza, aqui apenas apontada, das qualidades sensíveis, atravessando pelo meio as diferenças simbólicas.

Aqui também a recusa é apenas um momento, ponto de articulação para outros modos de subjetivação da relação entre corpo e mundo. No atrito entre os corpos, no lusco-fusco crepuscular, o próprio mundo se faz equívoco - eis o enigma - elidindo sujeito e objeto em um campo de ressonâncias. Como aquele objeto que vem do mar em Eupalinos, sem que saibamos se é da natureza ou feito pelos homens, se é matéria ou espírito, vem à tona essa experiência virtual e espectral poderosamente ambígua, que o cotidiano moderno submete ao crivo da razão e do olhar.

Nesse contínuo, como numa tradução infinita, com infinitas dobras e reentrâncias, chegamos ao ponto mesmo de não saber o que é Valéry ("Este teto tranquilo onde caminham pombas/ entre pinhos palpita, palpita entre tumbas" [OE, p. 147]) e Drummond (1987), cujo columbário (“já cinza se concentra, pó de tumbas/ já se permite azul, risco de pombas" [p. 238]), quando o modo como a morte esculpe a vida, delineia outra potência dos modos de existência.

Isto é, como em Cabral, aqui também ressoa a poética dupla valeriana em um grau de densidade e complexidade que apenas conseguimos apontar, tornando mais espessos e enigmáticos a vida e os muitos riscos que a atravessam. ${ }^{10} \mathrm{~A}$ hesitação se prolonga por muitos meios (entre a epígrafe de Valéry e os últimos versos que ecoam o "Cemitério marinho", pondo do avesso o columbário), o começo e o fim, o outro e o mesmo, os

10 Para corroborar a importância de Valéry nessas poéticas, veja-se Süssekind (2001), Gledson (2003) e Zular (2014), entre outros. 
ecos da tradução e o poema. Contínuo que interrompemos aqui, por força do nosso percurso, mas que se prolongaria infinitamente nesse curto-circuito enigmático e inebriante de dois poetas do alcance de Valéry e Drummond.

\section{A ARTE DAS RECUSAS (E DOS CADERNOS)}

A partir dos anos 1950, é principalmente a geração mais jovem formada ainda no entorno da Geração de 45 que dará continuidade à recepção crítica de Valéry no Brasil, seja como parte de um desdobramento do movimento da poesia concreta, seja como diálogo poético como na poesia de Sebastião Uchôa Leite ou como resgate de uma potência crítica na obra de João Alexandre Barbosa. Mas é a contrapelo, por um conhecido poema de Murilo Mendes (1995, p. 706), parte 4 do longo "Texto de informação" da seção "Sintaxe", de Convergência, escrito de 1963 a 1966 e publicado em 1970, que gostaríamos de começar esse resgate:

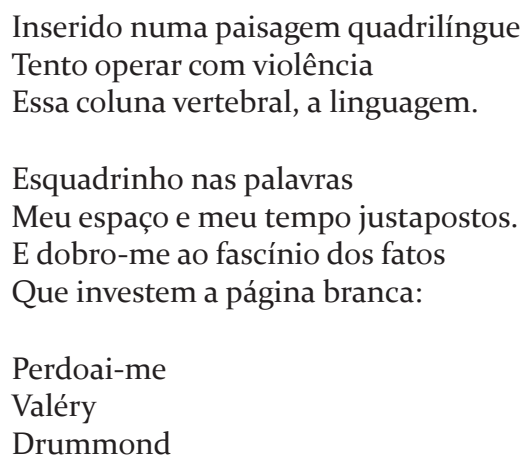

A forte presença de Valéry, pressentida porém raramente expressa na obra de Murilo Mendes, vem à tona aqui, no bojo dos anos 1960, como uma recusa da recusa: o fascínio dos fatos que o ligariam a Webern, João Cabral, Ponge e Mondrian. Mas, curiosamente, essa dupla recusa é muito mais próxima da poética dupla de Valéry do que se poderia imaginar. Claro que na efervescência dos anos 1960 é simples perceber como o aquecimento e precipitação dos movimentos sociais de todas as ordens colocava em jogo um desejo de imediatidade pouco valeriano, embora os fluxos de desejo e de transformação não pudessem estar mais próximos do "mar", por trás dos fatos, como as forças sob as formas. Assim, a contrapelo do que afirma explicitamente, a dinâmica que Mendes instaura no "texto de informação" vai ser a tônica complexa da melhor leitura de Valéry: paisagem e língua, 
coluna vertebral e linguagem, travessia de espaços e tempos - da potência de virtualidades e de campos de força - de vida e de acontecimentos que colocam em questão a simplicidade dos "fatos" e, por isso, fascinam -, da página em branco com suas múltiplas temporalidades e metamorfoses.

A posição de Murilo Mendes (2017, p. 154) complexifica e torna mais rica a situação de Valéry como sobrevivência de sobrevivências e como um clássico que coloca em questão o classicismo para operar outros tempos e dinâmicas, como mais tarde o próprio Mendes faria no setor "texto délfico" de Poliedro, escrito em 1965/1966 e publicado em 1972: "Duas obras-primas da literatura grega: a Odisseia e Le cimetière marin”. Mendes toca aqui, entre irônico e admirado, na travessia de tempos e variações que se cruzam sobre, sob e através da teleologia que não percebe a potência da pergunta: "Que seria de Delfos, agora, sem Mozart ou Hölderlin?" (MENDES, 2017, p. 148) ou ainda "Nijinski seria possível sem Delfos?” (p. 149).

É justamente nesse intervalo, entre o início dos anos 1960 e meados de 1970 que Valéry voltará a ser traduzido. Assim, em 1960, o Cemitério marinho começará sua série de retraduções, a primeira delas do próprio Damasceno, em uma edição de 130 exemplares, feita por uma pequena editora da Bahia. Damasceno (VALÉRY, 1960, pp. 51-52) refaz o poema, como se pode notar nos seus "comentários do tradutor":

[...] quanto aos objetivos que miramos numa segunda versão do poema. Se da primeira vez, por motivos óbvios, impunha-se respeito à literalidade, com evidentes prejuízos para o trabalho de recriação artística, desta feita buscamos captar o espírito da obra, preservando-o de estrofe a estrofe, aceitar o estímulo para o difícil e atraente jôgo metafórico e rítmico soluções atinentes tôdas à expressão verbal, no que esta importa em recursos vocabulares, fônicos, rímicos e rítmicos são aqui apresentados como possibilidades e correspondências da língua portuguesa - não como transladação de uma língua a outra. ${ }^{11}$

Mas é a partir do início dos anos 1970, que Valéry passará a circular de outro modo no Brasil. Nesse sentido, o trabalho do crítico João Alexandre Barbosa e sua relação com os irmãos Campos é fundamental, uma vez

11 Essas múltiplas temporalidades - "milumtempos de milumpoemas" - apontam, como mostrou Lucius Provase (2016), para uma grande transformação dos regimes de historicidade nos anos 1970 e que será responsável, ao seu turno, por uma grande transformação da relação entre tradução e criação, no desdobrar do movimento da poesia concreta, bem como na dinâmica das próprias obras que passam a internalizar aquilo que Provase chamou de "historicidade distorcida". Neste ensaio, nosso propósito será acompanhar essas ideias, tendo Valéry e sua relação com Mallarmé como eixo. 
que sua leitura de Valéry é pautada pela circulação de outro grande poeta francês no Brasil, o mestre de Paul Valéry, Stéphane Mallarmé. Nesse sentido, é preciso lembrar que, ainda que o Mallarmé de Um lance de dados apareça em todos os manifestos concretistas desde os anos 1950, é somente em 1974 que Augusto de Campos, Haroldo de Campos e Décio Pignatari publicam no Brasil a primeira antologia da poesia mallarmeana. A data coincide com a publicação do ensaio "Mallarmé segundo Valéry", de João Alexandre Barbosa, em que se reforça academicamente no Brasil a imagem valeriana de um crítico de primeira linha, mas que não havia compreendido, no que diz respeito à fatura poética, o alcance da revolução operada por aquele lance de dados de Mallarmé.

Há aí uma interpretação que separa o Valéry poeta do Valéry crítico. E que coloca em relevo a radicalidade da sua teoria em relação à sua poesia. É verdade que essa separação dos textos críticos e poéticos do autor continua ainda a levantar muitas questões. É por exemplo a conclusão a que chega William Marx (2002, p. 323) quando afirma:

A obra de Valéry oferece um caso interessante de oposição interna: enquanto seus textos críticos procuram esvaziar da reflexão o referente concreto, de maneira a privilegiar a construção teórica, seus poemas, ao contrário, buscando uma ancoragem na mais material das realidades, ali manifestam uma singular pregnância do sujeito.

Como em 1974 estamos em um momento em que a radicalidade da obra final de Mallarmé está na ordem do dia - Haroldo de Campos acaba de publicar a primeira tradução de Um lance de dados -, e o que vai interessar aos leitores de Valéry será precisamente a construção teórica "esvaziada de referente". ${ }^{2}$ Essa adesão à parte mais abstrata da teoria valeriana leva Barbosa a escolher, como um dos momentos mais importantes da interpretação do "discípulo", aquele no qual Valéry salienta que "o rigor das recusas, a qualidade das soluções rejeitadas, as possibilidades proibidas, manifestam a natureza dos escrúpulos, o grau de consciência, a qualidade do orgulho, e até os pudores e vários medos que podemos sentir em relação aos julgamentos futuros do público" (OE,

12 É importante frisar que essa é apenas uma leitura possível da relação Mallarmé-Valéry e que mesmo a tradução de Haroldo de Campos com seu aparato de notas não descuida totalmente do aspecto semântico. Como lembrou Eduardo Sterzi informalmente, há ainda uma reatualização política do gesto mallarmeano como "o poeta em greve", e Pignatari propõe uma radical "tridução" que ideogramatiza a multiplicidade de sentidos de "A tarde de um fauno". 
I, p. 641).13 Esse gesto de recusa de Mallarmé é compreendido pela crítica como um tipo de criação que, "desintegrando os elementos da tradição, opta pelo futuro” (BARBOSA, 2007, p. 44).

O acerto de contas e a admissão do alcance do anacronismo deliberado que quer "perpetuar as ninfas" também em Valéry se dará no mesmo ano de 1974, com uma nova retradução do "Cemitério marinho", dessa vez por Jorge Wanderley, pós-faciada por Barbosa sob o título "Leitura viva do cemitério”. Aqui não é mais o Valéry autor dos ensaios críticos que orienta a leitura, mas o mais radical e complexo poeta que é também autor do Cadernos. Assim, no primeiro parágrafo do texto de Barbosa (1984, p. 51) lê-se:

O aparecimento da versão brasileira do poema de Paul Valéry por Jorge Wanderley coincide com um momento da maior importância na história da obra do poeta francês: a publicação, em forma comercial, dos seus Cahiers, reveladores (para quem ainda não lera a edição fac-similar do CNRS) de um espantoso escritor que, durante cinquenta e um anos (1894-1945), fora anotando o movimento de seu espírito inquieto.

Para surpresa da maioria de seus leitores, um escritor autobiográfico, talvez fosse melhor dizer uma linguagem autobiográfica, buscando, sem cessar, os limites da lucidez por entre o esvaziamento das linguagens.

Sem perder de vista a consciência moderna que atravessa a reflexão valeriana, Barbosa coloca em evidência a surpresa produzida pelos Cadernos. Esses Cadernos levam o crítico a estabelecer aqui outra relação com o Cemitério, acionando para tanto um outro crítico-escritor:

Foi T. S. Eliot quem escreveu que "a poesia não é um perder-se na emoção mas um escapar da emoção; não é a expressão da personalidade mas uma fuga da personalidade". Acrescentando bem depressa: "Porém, de fato, somente aqueles que têm personalidade e emoção sabem o que significa querer escapar dessas coisas".

Algumas questões maiores se impõem aqui. Com a publicação dos cadernos e a radicalidade de suas reflexões, Valéry deixa de ser visto como um discípulo menos ambicioso e mais oficial de Mallarmé, o que muda tanto a historicidade de sua própria obra, como a historicidade de sua recepção no Brasil. A partir dali, a obra de Valéry não é mais a mesma que

13 “[...] la rigueur des refus, la qualité des solutions que l'on rejette, des possibilités que l'on interdit, manifestent la nature des scrupules, le degré de conscience, la qualité de l'orgueil et, mêmement, les pudeurs et diverses craintes que l'on peut ressentir à l'égard des jugements futurs du public". 
leram os modernistas, e começa a ficar clara a artificialidade da construção externa e parcial de um poeta formalista. É o que atesta ainda William Marx (2002, p. 329), a propósito justamente de Eliot que, em 1924, no momento de qualificar Feitiços, que acabava de ser publicado,

\begin{abstract}
[...] emprega quase palavra por palavra as fórmulas chave que ele usava no seu ensaio de 1919, 'Tradição e talento individual', para descrever o trabalho do poeta ideal [...] como se o poeta Valéry viesse satisfazer ponto por ponto ao programa fixado pelo crítico Eliot. E é nesse momento que a relação entre o poeta Eliot e o crítico Eliot fica muito mais problemática.
\end{abstract}

Essa é a hipótese central do trabalho de Marx, a qual, é preciso dizer, quer-se um trabalho essencialmente pautado nos escritos críticos publicados por Valéry. O próprio Marx, no entanto, em um movimento análogo ao de Barbosa, volta ao trabalho de Valéry em outros termos. E dessa vez ele o fará a partir dos cadernos, o que o leva a compreender uma poética dupla. Segundo ele, ao lado da poética dita "formalista", pautada na poesia como exercício, na arbitrariedade do acabamento e na natureza acidental da publicação, há uma outra poética da voz, das forças sob as formas, da variação dos corpos, dos afetos e dos modos de existência.

João Alexandre Barbosa (1984, p. 57), ao seu modo, reconhece também essa duplicidade dentro daquilo que chama, na sua leitura do Cemitério, de jogo entre imobilidade e movimento, percebido por uma consciência que se esforça por manter a tensão entre dois termos contraditórios, Cemitério e mar. Veja-se como aqui também se vislumbra a relação entre a espuma dos fatos e o campo de forças do mar, a imobilidade da obra publicada e o movimento perpétuo dos cadernos, a determinação e a indeterminação que se sobredeterminam nessa nova fase de leitura da obra de Valéry. Afinal, o que não se fixa, não é nada. O que se fixa, está morto. Nesse intervalo, na leitura do intervalo como propunha Barbosa, jogam-se as cartas e as possibilidades da arte, como veremos adiante em outro texto seminal de 1974, o Semiótica e literatura de Décio Pignatari, no qual, em diálogo com C. S. Peirce, desenvolve-se um quase-método de Valéry a partir dos textos deste sobre Leonardo da Vinci.

Esse jogo entre mobilidade e imobilidade, entre variação e regularidade, servirá ainda para a leitura de Barbosa dos manuscritos do poema, ao apontar que, ao lado das variantes, há duas estrofes que não se modificam e que se encontram aproximadamente no meio do poema. Elas correspondem às estrofes XIII e XIV das 24 que compõem o poema. Nesse "centro geométrico" encontra-se o verso "eu sou em ti 
a secreta transformação”. Segundo Barbosa (1984, p. 57, grifo nosso), "transformado por tudo o que no poema até ali foi dito, este je aponta para a realização efetiva do poema enquanto mediação entre os estados de emoção e afetividade e aquele outro, soberano, que se quer atuante, o da inteligência e da reflexão criadoras". E ele insiste na reflexividade metalinguística ao afirmar que os termos utilizados:

[...] descrevem a parábola do exercício poético: entre a pureza do "grande diamante" e a aceitação daqueles que, sob a proteção da "noite pesada de mármores", encontram o instante absoluto, está o poema que recusa o "vago" e constrói sua teia de impasses entre um "povo errante".

Portador do movimento, desde que linguagem, o poema não só constrói a sua teia mas destrói a possibilidade do absoluto. A recusa do "vago", contraposto à aceitação do "povo errante", determina os limites dentro dos quais o poema se incrusta como mediador. (BARBOSA, 1984, p. 59, grifo nosso)

A recusa Mallarmeana do vago pela sugestão, como mostra Barbosa, desdobra-se aqui em uma recusa do absoluto, mesmo do acaso absoluto, recusa da "Ideia" e outros entes abstratos que com suas grafias maiúsculas instauram uma determinação absoluta. O Cemitério marinho é também uma grande reflexão sobre o naufrágio. Há aqui uma indeterminação que produz uma tensão constante, movente, entre o grande diamante, as tumbas, o mar e os corpos, os pequenos "eus" com seus arrependimentos, dúvidas, restrições. Entre os afetos, a memória, as imagens, os mortos e o trabalho de luto que se perfaz lado a lado com a consciência e o ato poético. Nesse intervalo, Barbosa (1984, p. 6o) vê um laborioso gesto tradutório:

\begin{abstract}
Dois níveis de tradução, portanto: aquele que, numa primeira leitura revela a transformação da experiência mediterrânea de Sète num motivo para a meditação através do poema e aquele que implica na reflexão sobre os próprios limites da transitividade entre experiência e poema. A passagem de um para outro nível, num contexto de inclusão permanente que é o contexto poético, é o que, sem dúvida, torna o poema denso, exigindo do leitor uma constante reduplicação de seus termos.
\end{abstract}

Trabalho de luto, portanto, trabalho sobre os limites da transitividade, tradução infinita não apenas entre línguas, mas entre experiência e poema. E o leitor dessas traduções, como da tradução do poema, deve desdobrar a reduplicação desses termos, pois que a questão se torna o sentido, a direção, o movimento, com que essas múltiplas camadas que 
habitam as relações se sobredeterminam. ${ }^{14}$ Nesse sentido, não é à toa que voltamos, em 2018, a essa retomada de Valéry nos anos 1970, pois vivemos o mesmo refluxo, após um processo de redemocratização, de um viés autoritário. ${ }^{15}$ Ainda não como o de 1974, mas a complexa abertura, antes como hoje, procura produzir uma discursividade e uma temporalidade que achatam a multiplicidade de tempos, as contradições, os projetos truncados, as marcas da violência, que impedem todo o trabalho de luto. Essa tradução continua entre o que fica e as ausências, lugar por excelência onde a linguagem, feita experiência, articula uma outra relação entre os cemitérios e o mar da história.

\section{4: VALÉRY E O FIM DAS UTOPIAS}

Se aceitamos, no entanto, que o "mar desde sempre recomeça", a questão que se coloca após a ditadura é como e por onde recomeçar. Sabemos que a transição democrática se mostrou imensamente problemática e, especialmente no ano de 1984, mostrava-se penosa com a rejeição das eleições diretas, o que levou um apoiador do golpe que instaurou a ditadura civil-militar, José Sarney, à presidência.

1984 é também o ano da publicação de "Poesia e modernidade: da morte da arte à constelação. O poema pós-utópico" de Haroldo de Campos, lido primeiramente no México, em homenagem ao aniversário de 70 anos de Octavio Paz. Entre outras importantes reflexões, o ensaio aponta para aquela historicidade distorcida que vinha se delineando desde os anos 1970 e que encontra sua formulação mais contundente como "crise das utopias" e "crise das ideologias". Ele reconhece que os anos 1960-1970, por mais que tenham trazido uma revolução comportamental e contracultural, corresponderam à imposição de um capitalismo

14 Esse complexo jogo de forças e de formas desloca a oposição contraditória razão/ emoção, para instaurar uma contradicção, como propõe Fabio Roberto Lucas (2017), que sobredetermina as relações entre as múltiplas camadas da experiência sensível, afetiva, corporal, imagética, mental, cujos termos não se totalizam, mas se atualizam na enunciação (na dicção) em um espaço de reenvios que possibilitam modulações (passagens) de um a outro. Sim, há o cálculo, a forma, o pensamento, a razão, mas nenhum deles, nem mesmo o mais musical, significativo ou sugestivo, produz uma arché; nenhum deles se coloca em um ponto hierárquico como polo de determinação do ato poético, tanto na produção como na recepção e, claro, no trabalho de tradução como propomos.

15 No momento em que acabamos de saber, pela revelação de documentos da Cia (Central de Inteligência Americana), que o general Geisel era o responsável direto não apenas pela abertura democrática, mas também pela continuação da execução de opositores ao regime. 
"imperial" e "selvagem" e a um Estado repressivo e uniformizante, que transformou os revolucionários em burocratas. Nesse contexto, a poesia se esvazia de sua função utópica. O que resta, segundo ele, é uma poesia pós-vanguardista, pós-utópica. Essas colocações não poderiam ser mais valerianas pela dupla violência unívoca do Capital e do Estado que se sustentam cinicamente quando a moeda e o poder perderam os lastros que o sustentavam (Cf. PROVASE, 2016). A recusa valeriana desse estado de coisas faz eco às recusas drummondianas, cabralinas, marioandradinas... nesse movimento constante de fluxos e refluxos da ligação da poesia brasileira com os polos construção e espontaneidade, modernização e vanguardas, onde sempre reaparece a figura de Valéry.

No contexto específico do ensaio de Haroldo de Campos, essa passagem se faz com uma ênfase central na tradução. Como se trata de uma época de "sínteses provisórias", que admitiria a existência de uma "história plural”, a tradução permitiria "uma apropriação crítica do passado", não mais sincrônica, nem diacrônica, mas como uma pluralidade de tempos possíveis. Assim, conclui-se que

[...] a poesia pós-utópica [...] tem na operação tradutória um dispositivo crítico indispensável. O tradutor, como diz Novalis, "é o poeta do poeta", o poeta da poesia. A tradução - vista como prática de leitura reflexiva da tradição permite recombinar a pluralidade dos passados possíveis e presentificá-la como diferença, na unicidade hic et nunc do poema pós-utópico. (CAMPOS, 1997, p. 269)

E, alguns meses depois, em janeiro de 1985, Haroldo de Campos publica "Paul Valéry e a poética da tradução: as formulações radicais do célebre poeta francês a respeito do ato de traduzir". Valéry pode então ser pensado como um autor-chave na elaboração teórica do poema pós-utópico. É a partir das "Variações sobre as bucólicas" que Campos coloca em relação aquilo que ele chama de "formulação radical" de Valéry e as reflexões sobre tradução, feitas por Borges e Benjamin, que o levarão ainda uma vez a Mallarmé. Diz ele: "Valéry e Benjamin se reconciliam em Mallarmé" (CAMPOS, 2013, p. 71). O mais importante para Campos (p. 72) é sobretudo a aproximação entre escritura e tradução, que se encontra no ensaio de Valéry sobre as Bucólicas, assim como o fato de Valéry observar que traduzir é uma "aproximação da forma” e, acima de tudo, "discussão por analogia”. E arremata: "discutir por analogia não é uma simples duplicata ou imitação, isso significa algo ativo e transformador". 
Essa tomada de partido haroldiana ressoa o já citado livro de Décio Pignatari, Semiótica e literatura, especialmente se tomado como uma outra pedagogia do signo, a qual vinha se formulando desde os anos 1970 a partir do "quase-método an-a-lógico" de Valéry-Vinci: "o segredo está nas relações” (PIGNATARI, 1974, p. 19). Relacionar qualidades que se assemelham, mas também relacionar diferenças em um contínuo. Uma lógica imaginativa que, recusando os nichos de especialistas, atravessa as artes, a ciência, a lógica e a estética. Como gesto pós-utópico, não se trata de colocar o pensamento, a sensibilidade e a arte em uma única direção homogeneizadora, mas de produzir tanto contínuos (a continuidade entre as coisas) quanto sistemas discretos (de "variar as imagens, de combiná-las, de fazer coexistir a parte de uma com a parte de outra, e de perceber, voluntariamente ou não, a ligação de suas estruturas" [p. 19]), relacionar indeterminações e determinações ("o mundo é irregularmente semeado de disposições regulares” (p. 19), acatar desordens e refutar ordens (a ordem e a desordem são dois inimigos da humanidade). Enfim, atentar para a historicidade das relações, suas temporalidades e qualidades heterogêneas que possibilitam pensar: "se tudo fosse irregular - ou regular - não haveria pensamento" (p. 20).

O pensamento que atravessa as coisas e que não é uma capacidade apenas humana, se dá por essa passagem de um campo sensível a outro, de um domínio de experiência a outro, de um afeto a uma cor, a uma palavra, a um som em reenvios infinitos: "Ele [Leonardo] sabe do que é feito um sorriso: pode colocá-lo na fachada de uma casa ou nos meandros de um jardim” (VALÉRY apud PIGNATARI, 1974, p. 19). Nesse quase-método analógico, descobrir vem antes de procurar, e ensinar é fazer descobrir. É todo um outro mundo de possibilidades que se abre e outro modo de relacionar acaso e ordem. Mas, sobretudo, é um modo de não separar as práticas das formas de pensamento. Para Valéry, Leonardo era um filósofo porque não separava o fazer do pensar.

Essa colocação em ato do pensamento ligado à prática e à relação entre as práticas também marca a operação tradutória dos irmãos Campos e de Décio Pignatari, que não separavam traduzir de pensar, como não separavam criar de traduzir. Valéry será então uma peça importante da reformulação da poética do traduzir desses poetas. E é nesse quadro amplo de questões que vem a público, também em 1984, "Paul Valéry: a serpentee o pensar", em que vemos lado a lado a tradução de "Ébauche d'un serpent", assim como excertos dos Cadernos com vários desenhos concernentes à 
imagem de serpentes. É a primeira tradução, até o momento, de parte dos cadernos e feita a partir da edição fac-símile do Centre National de la Recheche Scientifiques (CNRS), e não daquela organizada por tópicos da Pléiade/Gallimard. A escolha do esboço, como o esboço do método, quase-método, por Augusto de Campos (1997, p. 21), é justificada por se tratar do poema "mais rico" de Feitiços no que concerne à utilização de "todos os artifícios da palavra”, ou mais, por se tratar de um monólogo que "passa por todos os estágios da voz humana, da ternura à cólera, do desafio à hipocrisia, da eloquência à persuasão, da tristeza ao orgulho, do grito à argumentação, numa ironia quase contínua”. Vê-se como a voz que sai da linguagem, mais do que a voz da linguagem, passa a ser a questão.

Por todo o livro, desde sua concepção, o aspecto gráfico, os jogos sonoros, as mudanças de tom, a "sensualidade da linguagem", sua presença, se mistura ao tema da ausência, de um suposto deus oculto de um mundo que não é mais que um defeito na pureza - insuportável, mesmo para deus - do não-ser. Augusto de Campos radicaliza a farsa metafísica do poema, fazendo girar os pontos de vista e as posições enunciativas que derivam da queda da onipresença da voz divina.

Entre a sonoridade e o nada, a presença e a ausência, o som e o sentido, o corpo e a linguagem - na elaboração desses limiares - se joga a política do pensamento dada pela associação, por Augusto, da serpente que morde o próprio rabo e o ato de pensar. É a serpente como símbolo do intelecto e da sabedoria que vai ressoar na forma mesma das palavras: "Há quem afirme ser a serpente, desde a Antiguidade, um símbolo da sabedoria, como o indicaria o nome grego ophis (serpente), um quase-anagrama de sophia (sabedoria). Eu me pergunto se Valéry não teria consciência de que a palavra penser é um palíndromo silábico de serpent" (CAMPOS, 1997, p. 11).

Esse lugar da serpente, como posição enunciativa e ponto de vista, sensual e intelectual ao mesmo tempo, revela em muito um horizonte de abertura democrática que se delineava como recusa da voz grossa, violenta e autoritária da ditadura. A inteligência do país do futuro no seu QG desértico de Brasília aqui encontra um pensar que é sinuoso, ambíguo, sensual, com todas as imperfeições e os defeitos de uma prática, um contínuo que liga a serpente ao pensamento (serpente : penser) e o presente à serpente (presente : serpent), em um jogo de recirculação que aproxima Valéry de Mallarmé e Joyce, pela última estrofe da primeira versão do poema, assim traduzida: "e entre a cintilação tremente/ de sua cauda eternamente/ eternamente o fim morder" (CAMPOS, 1997, p. 23). 
É por esse caminho mais radical da leitura de Valéry que vemos outro valeriano confesso, Sebastião Uchoa Leite (1989), propor uma espécie de variação/tradução de "Esboço de serpente", no mesmo ano de 1984:

\author{
Outro esboço \\ A serpente semântica disse: \\ não adianta querer \\ significar-me \\ neste silvo. \\ Meu único modo de ser é a in \\ sinuosidade e a in \\ sinuação. \\ não é possível pensar \\ a verdade \\ exceto como veneno \\ 1984 .
}

Uchoa Leite leva aqui ao limite a hesitação entre o sentido do poema e o silvo que atravessa toda significação, silvo que se coloca ao mesmo tempo como um grito do sensível na construção do sentido e como um fundo existencial opaco e intrasponível. Resta um modo de ser, um modo de serpente, in-sinuosa in-sinuação por sua vez também atravessada por algo que escapa e excede: só há verdade se tomarmos o pensar como uma secreção (algo corporal, da ordem do sensível, portanto) que atinge o outro (ainda que como defesa), colocando o pensamento como um modo de lidar com a alteridade (sobretudo de si mesmo) e a morte.

Tanto no livro-tradução de Augusto, quanto na poética de Sebastião Uchoa Leite exposta nesse poema, vemos que está em jogo um outro Valéry em um movimento que busca aproximar o poeta e o crítico, o poema e os cadernos, a experiência e o pensamento, ultrapassando as dicotomias que pautavam a recepção de Valéry e, de certo modo, como tentamos mostrar, também pautava os embates da poesia brasileira do século XX. Não se trata nem de hegemonizar nem de excluir o pensamento, e sim de apontar essa hesitação prolongada entre pensamento e voz, linguagem e corpo, razão e afeto. A poesia não é nem a regra, nem a ausência de regra, mas o espaço de relação entre a presença e a ausência, entre o presente e o passado, onde se joga a política, embora não seria exatamente esse o caminho que o país tomaria, mais próximo da versão definitiva do Esboço na qual há um esvaziamento da própria política da serpente-pensamento: "A sede que te fez tamanha/ Até ao ser exalta a estranha/ Onipotência que é o nada" (1986, p. 56). 
No limite da bricolagem do jogo linguístico se evidencia toda a força e toda a dificuldade dessa poética, como também é de onde redunda toda a beleza e o exagero da operação tradutória da poesia de Valéry. E Augusto de Campos continuará a perseguir a serpente valeriana. Em 1987 publica o monumental Linguaviagem, livro que ele próprio define como um exercício de crítica via tradução. Esse volume reúne poemas de Mallarmé ("Hérodias"), Valéry (“La jeune parque”, "La dormeuse”, "Les grenades", "Au soleil") e outros de Yeats, Keats e Bolk. Com efeito, Valéry aqui ocupa um lugar central, e a tradução de seus poemas compõe boa parte do livro. O ensaio de abertura, "De 'Herodias' à 'Jovem parca': uma arte de recusas", coloca Valéry em continuação e tensão com Mallarmé, mas, de todo modo, em um patamar que ainda não tínhamos visto desde sua retomada nos anos 1970. Graças aos poetas ligados ao movimento concretista, nesse momento pós-utópico, que também é uma retomada das leituras de sua formação no final dos anos 1940 início dos 1950, Valéry alcança outro aspecto e outro lugar.

Em um primeiro plano, impõe-se uma leitura da arte das recusas, da necessidade de rigor, de não se deixar facilmente levar pelo novo, pelo fácil, pelo banal. Um rigor que não é autoritário e que instaura uma outra relação com a norma. Produz-se assim uma recepção mais fina, que percebe a arte como essa passagem do arbitrário ao necessário, como espaço quase religioso onde o próprio sentido da existência se revela no refinamento infinito da elaboração da forma, atravessando o processo e o poema, o ato de escrita e o de leitura, mediado pela leitura-escrita da tradução. O que se dá a ver aqui, em surdina, é esse trabalho de inovação sem o culto da novidade, por ressonância de outros tempos, "por outros passos menos aparentes”. É uma recusa também da banalidade brutal da vida, atravessando a violência do presentismo em busca de outros modos de existência, outros afetos, outras formas de pensamento e regimes de imaginação.

A tradução se coloca aqui como reminiscência, como sobrevivência. Valéry dizia mesmo que uma época comoa nossa jamais teria inventadoalgo como a poesia. Ela é um espaço de ressonância de outras temporalidades e de outras imagens. Por isso a força da reatualização de figuras míticas como Herodias e a Jovem Parca. Elas são um modo de sobrevivência de imagens, como um modo de sobreviver ao trauma, no caso de Valéry, da primeira guerra na Europa. Sob o signo da guerra e da morte, o mistério 
e a opacidade se impõem como espaço de recirculação das imagens e de transformação do pensamento.

A Jovem Parca que tece os fios da vida, separa o vivo do morto, como a cabeça cortada do cântico de São João em "Herodias", "que repele ou corta/ os antigos desacordes/ com o corpo" (CAMPOS, 1986, p. 34). Essa impossibilidade de subjetivação da própria experiência e do próprio corpo aponta um limite intransponível da reflexividade romântica. É alguém que chora ali, "tão próxima de mim a ponto de chorar", como se o sujeito fosse inacessível para si mesmo: "eu me via me ver" (p. 35), preso no labirinto narcísico do olhar, como uma serpente que acaba de me morder. E de novo estamos enredados no oroboro valeriano em um grau de densidade e clivagem quase insuportáveis.

Mas essas ruínas têm uma certa rosa. É daí que sai o pronome oblíquo, não como uma clivagem do sujeito, mas como um diferir do mesmo, traduzido magistralmente por Augusto como uma misteriosa "MIM", diferente do eu e que não é um espaço alienado, mas um estranho que se internaliza na transformação dos espaços fantasmáticos em que opera o luto (Cf. NODARI, 2018). Como tradução, como uma outra relação com o pensamento, como espaço mitográfico, como uma outra forma de sobrevivência, como um atravessamento de temporalidades. O luto, diante da perda que ecoa aqui um outro luto, mais oculto de tão óbvio: o luto da saída do golpe militar que o Brasil se recusava (e ainda se recusa) a fazer.

\section{VALÉRY E A ABERTURA}

Linguaviagem sai em 1987, um ano antes da promulgação da Constituição de 1988, na qual se selava um novo - complexo e paradoxal - pacto social no Brasil. Na onda da abertura e atento à complexidade do processo e mesmo da relação entre poética e política em Valéry, João Alexandre Barbosa publica um excelente conjunto de ensaios que sai em 1991 sob o título Variedades. Era o momento propício para retomar a complexidade do crítico e ensaísta e dar-lhe uma dimensão que atravessava a poética, a estética e a literatura para dialogar com a filosofia e a (quase) política. Desde a introdução, a densidade e o alcance da empreitada valeriana são colocados como corolário da compreensão da poesia que o leva às mais instigantes aventuras da "alquimia do espírito", como proposto no pós-fácio de José Aguinaldo Gonçalves (1991, p. 219). 
É um momento de abertura política e de um pensamento político da abertura (e seus limites) que esses ensaios dão a ver, entre o pensamento e a voz, "o som, o sentido, o real e o imaginário, a lógica, a sintaxe e a dupla invenção do conteúdo e da forma". O poema em ato aciona todo o universo de possibilidades do espírito, entre os limites da razão de M. Teste e o rigor imaginativo do fazer/pensar de Leonardo da Vinci. Traça-se aqui também, além das referências a Poe, Mallarmé e Eliot, uma outra constelação valeriana formada por Borges (que amava "os lúcidos prazeres do pensamento e as secretas aventuras da ordem") e Italo Calvino que, nas suas Norton Lectures, colocava Valéry como signo da multiplicidade e da consistência; "a inteligência da poesia, mas, ao mesmo tempo, da ciência e da filosofia: uma inteligência como a de Valéry enquanto pensador e prosador" (CALVNO, 1999, p. 12).

Esse momento do Brasil era propício a esse espaço maior de reflexão e sutileza na compreensão da escrita valeriana, somado ao grande aumento do número de universidades e editoras. O fato é que, ao se completar cinquenta anos da morte do poeta, em 1995, grande parte de sua obra em prosa começou a ser publicada no Brasil, com algumas exceções lastimáveis, como, por exemplo, a inexistência de uma tradução de seus Cahiers, nem que fosse de uma antologia como aquela publicada pela Gallimard na coleção Pléiade, nos anos 1970. Concretamente, ao longo desses anos foram traduzidos Eupalinos ou l'architecte (1995), L'âme et la danse et autres dialogues (1996), Monsieur Teste (1997), Introduction à la méthode Léonard de Vinci (1998), Degas danse dessin (2003), Alphabet (2009), Mon Faust (2010), Mauvaises pensées et autres (2016), Amphion (2017).

Desse modo, começa a aparecer não só o ensaísta Valéry, mas o ficcionista, o escritor de diálogos, de peças dramatúrgicas, de reflexões esparsas como os Cadernos e mesmo de libretos de ópera. Como bem viu Marcelo Coelho (1996, p. 13), no prefácio a alma e a dança: "é nesse espaço entre corpo e espírito, entre som e sentido, entre sensualidade e razão, entre consciência e transporte que se movem os diálogos traduzidos neste volume”. E não só nesses diálogos, pois também nas outras traduções começa a aparecer o Valéry compreendido no seu movimento e na sua multiplicidade, agora com publicações completas do ciclo Teste e do ciclo Leonardo.

E foi preciso esperar até o ano de 2013 para que aparecesse uma nova tradução acompanhada de um estudo. Fragmentos de Narciso e 
outros poemas, organizado por Juliao Castañon Guimarães, é a única publicação de um livro de poemas de Valéry desde os trabalhos de Augusto de Campos. ${ }^{16}$ Professor, também poeta e tradutor de outros autores franceses, entre os quais Mallarmé, Guimarães dá continuidade aos trabalhos de Campos e Barbosa. No seu ensaio de abertura, ele retoma um conjunto considerável de questões que animam o debate em torno da obra de Valéry. Ele reconhece aquelas questões genéricas atribuídas à obra valeriana (dificuldade, formalismo, intelectualidade), mas o que lhe interessa sobretudo é a tensão que existe entre o trabalho do poeta e o do crítico. A proximidade entre essas dimensões de sua obra como interpretado por Hytier (2003) e Lawler (1963), revelam uma íntima relação entre os manuscritos, as notas, os cadernos e os poemas. Acompanhando aqui de perto Judith Robinson-Valéry (2000, p. VII), toma-se o partido de que a poesia de Valéry é inseparável de sua prosa, o que não exclui a recomendação de que se leiam os poemas, de preferência em voz alta, para perceber o quanto "a voz humana está presente em toda essa poesia, vibrante e próxima”.

Transmigrações, modificações, intertextualidades, inter-relações, movências, combinações, proliferações são as palavras constantemente retomadas ao longo de ensaio de Guimarães, no qual encontramos, claro, um conjunto considerável de páginas dedicadas ao Fragmentos de Narciso. Em um novo lance de relações, Guimarães percorre a gênese do tema do Narciso, que o leva a traduzir (entre outros poemas, cujas inter-relações são mais sutis ou menos evidentes $)^{17}$ o poema "Narciso fala", do Álbum de versos antigos. Mais uma vez, acionamos a temporalidade complexa da mitologia valeriana ao apresentar Narciso em fragmentos - rompendo essa forma reflexiva e se aproximando de um antinarciso - e trazendo para dentro do poema a noção de mito como uma estrutura movente em

16 É preciso frisar que em algumas antologias de poesia em tradução encontram-se alguns poemas de Valéry, os quais já tinham sido traduzidos anteriormente. É o caso de "Les pas" em Poesia alheia (org. e trad. Nelson Ascher, Rio de Janeiro, Imago, 1998); dos poemas "Les pas", "Les grenades" e "Le cimetière marin", na Antologia da poesia francesa (org. e trad. Claudio Veiga, Rio de Janeiro, Record, 1991); "Le cimetière marin” em O mundo como ideia, de Bruno Tolentino (São Paulo: Globo, 2002); e também em O prazer do poema: uma antologia pessoal, de Ferreira Gullar (Rio de Janeiro, Edições de Janeiro, 2014). Veja-se que o "Cemitério marinho" voltou nos anos 2000 a ser traduzido por dois importantes poetas brasileiros.

17 De Album de vers anciens, ele traduz "Hélène", "Au bois dormant", "Le bois amical”, "Les vaines danseuses", "Narcisse parle", "Épisode" e "Air de séramis"; e de Charmes, "Fragment du Narcise" e "Palme". 
contínua variação. Claro que essa variação aqui assume um outro aspecto relacionado ao processo de escritura:

O mais profícuo aqui é atentar para o fato de que uma leitura que associe os procedimentos de escrita de Valéry com poéticas combinatórias contemporâneas - e essa associação não pode ser estrita - se torna mais forte na medida em que ela incorporar às "versões definitivas" todos os diversos documentos do andamento de sua escrita. (GUIMARÃES, 2013, p. 29)

Para apoiar sua compreensão desse complexo que caracteriza o conjunto da obra de Valéry como uma rede em que não é preciso separar a obra publicada dos Cadernos, Guimarães retoma a reflexão de Jarrety (1992, apud GUIMARÃES, 2013, p. 31), para quem:

[...] considerando-se então a obra inteira, não podemos deixar de observar quanto, de um texto para outro, vêm ressurgir com frequência as mesmas questões abstratas que se tornaram literatura, ao mesmo tempo que elas escapam à literatura porque procedem também de um trabalho de ordem inteiramente diferente.

Assim, é o estatuto mesmo da obra valeriana que se reinventa no Brasil a cada edição, em função do modo como se coloca em relação a suas diferentes formas e seus diferentes espaços escriturais. A historicidade da escrita valeriana vai se imiscuindo na historicidade da poesia brasileira, desde as aventuras de décadas em torno da questão da poética, da retomada dos mitos, da crítica à modernização, da ética e da política da voz e do pensamento até os momentos mais marcantes da tradução, como as traduções do "Cemitério marinho" e dos "Fragmentos de Narciso", passando, sobretudo, por A serpente e o pensar. O que se delineia nesse arco é um interesse sempre renovado pela tensão entre o inacabamento e a forma, a imobilidade e o movimento, a arte como ato e o atravessamento de múltiplas temporalidades que foram assumindo, ao longo de quase um século, modos e tratamentos diversos, como exige uma escrita tão complexa e heterogênea.

\title{
THE POSITION OF PAUL VALÉRY TRANSLATED IN BRAZIL
}

\begin{abstract}
This article deals with the translations of Paul Valéry (1971-1945) published in book in Brazil from the decade of 1930, seeking a dialogue between translational projects and comparative literature, based on the notion of historicity.
\end{abstract}

Keywords: Valéry; Translation; Historicity. 


\section{REFERÊNCIAS}

ALMEIDA, Guilherme de. Poetas de França. 5. ed. São Paulo: Babel, 2010[1936].

ANDRADE, Carlos Drummond de. Claro enigma. In: Nova reunião. Rio de Janeiro: José Olímpio, 1987.

ANDRADE, Mário. O artista e o artesão. In: O baile das quatro artes. São Paulo: Martins Fontes, 1963, pp. 56-59.

ANDRADE, Mário. A raposa e o tostão. In: O empalhador de passarinho. Belo Horizonte: Itatiaia, 2002, pp. 110-113.

ANDRADE, Mario; BANDEIRA, Manuel. Correspondência Mário de Andrade E Manuel Bandeira. Org. M. A. de Moraes. São Paulo: EDUSP/IEB, 2001.

BARBOSA, João Alexandre. Leitura viva do cemitério. In: VALÉRY, Paul. O cemitério marinho. Trad. Jorge Wanderley. São Paulo: Max Limonad, 1984[1974], pp. 51-65.

BENJAMIM, Walter. Charles Baudelaire: um lírico no auge do capitalismo. São Paulo: Brasiliense, 1994.

BENJAMIM, Walter. Borges, leitor do Quixote. In: SCHWARTZ, Jorge (org.). Borges do Brasil. São Paulo: Unesp, 2001, pp. 51-76.

BOSI, Alfredo. História concisa da literatura brasileira. São Paulo: Cultrix, 1998.

CAMPOS, Augusto de. Linguaviagem. São Paulo: Brasiliense, 1987.

CAMPOS, Augusto de. A serpente e o pensar. São Paulo: Brasiliense, 1997[1984].

CAMPOS, Haroldo de. Transcriação. Org. Marcelo Tápia e Thelma Médici Nóbrega. São Paulo: Perspectiva, 2013[1985].

CANDIDO, Antonio. A educação pela noite. Rio de Janeiro: Ouro sobre Azul, 2011.

CARONE, Modesto. A poética de silêncio. São Paulo: Perspectiva, 1979.

COELHO, Marcelo. Prefácio. In: VALÉRY, Paul. A alma e a dança e outros diálogos. São Paulo: Imago, 1996.

DAMASCENO, Darcy. De Gregório a Cecília. Rio de Janeiro: Edições Galo Branco, 2007.

DIDI-HUBERMANN. Ninfa moderna. Rio de Janeiro: Contexto, 2013.

FRANCISCO JR., Eduardo. O livro vertebrado: a articulação dos poemas em Claro enigma de Carlos Drummond de Andrade. Dissertação (Mestrado em Teoria Literária e Literatura Comparada) - Faculdade de Filosofia, Letras e Ciências Humanas da Universidade de São Paulo, 2014. 
Remate de Males, Campinas-SP, v.38, n.2, pp. 631-682, jul./dez. 2018 - 667

GOETHE, Johann Wolfgang von. Três trechos sobre tradução. Trad. Rosvithe Frieses Blume. In: HEIDERMANN, Werner (org.). Clássicos da teoria da tradução: alemão-português. Florianópolis: UFSC, 2001, pp. 16-25.

GUIMARÃES, Júlio Castañon. Presença de Mallarmé no Brasil. In: Entre reescritas e esboços. Rio de Janeiro: Topbooks, 2010, pp. 9-55.

GUIMARÃES, Júlio Castagñon. Notas prévias. In: Fragmentos do Narciso e outros poemas. Trad. Júlio Castañon Guimarães. São Paulo: Ateliê, 2013.

GONÇALVES, José Aguinaldo. Pós-fácio. In: VALÉRY, Paul. Variedades. Trad. Maíza Martins Siqueira. São Paulo: Iluminuras, 1991, pp. 219 e ss.

GULLAR, Ferreira. O prazer do poema: uma antologia pessoal. Rio de Janeiro: Edições de Janeiro, 2014.

HOLANDA, Sérgio Buarque de. O espírito e a letra. V. 2. São Paulo: Cia. das Letras, 1996[1924].

LARANJEIRA, Mário. Poética da tradução: do sentido à significância. São Paulo: Edusp, 1993.

LATOUR, Bruno. Nous n’avons jamais été moderne. Paris: Découverte, 2006.

LEITE, Sebastião Uchoa. Cortes/toques. In: Obra em dobras. São Paulo: Duas Cidades, 1989.

LUCAS, Fabio Roberto. O poético e o político: últimas palavras de Paul Valéry. Tese (Doutorado em Teoria Literária e Literatura Comparada) - Faculdade de Filosofia, Letras e Ciências Humanas da Universidade de São Paulo, 2016.

LUCAS, Fabio Roberto. Modulation et résonances: l'acte poétique de Valéry. Revue Doctorales, Maison des Sciences de l'Homme de Montpellier, v. 4, 2017. Disponível em: <http://www.msh-m.fr/le-numerique/edition-en-ligne/doctorales>.

LUSSY, F. “Charmes” d'après les manuscrits de Paul Valéry: histoire d'une métamorphose. Paris: Lettres Modernes, 1990-1996. 2 vols., 806 p. (Vol. I termina na p. 386).

MELO NETO, João Cabral. Poesias completas. 4. ed. Rio de Janeiro: José Olímpio, 1986.

MARX, William. Naissance de la critique moderne. La littérature selon Eliot et Valéry. Arras: Artois Presses Université, 2002. (Col. Manières de Critiquer)

MARX, William. Les deux poétiques de Valéry. In: Paul Valéry et l'idée de littérature. 2011. Disponível em: <http://www.fabula.org/colloques/document1426.php>. Acesso em: 25 abril 2012.

MENDES, Murilo. Obras completas. Rio de Janeiro: Aguilar, 1995.

MESCHONNIC, Henri. Langage, histoire, même théorie. Paris: Verdier, 2012. 
NODARI, Alexandre. Alterocupar-se: obliquação e transicionalidade ontológica. Disponível em: <https://docgo.net/philosophy-of-money.html?utm_source=alterocupar-se-obliquacao-e-transicionalidade-ontologica>.

OLIVEIRA, Gustavo Ponciano Cunha; SOUZA, Jamesson Buarque de. Drummond e Valéry: enigmas eventuais. Itinerários, Araraquara, n. 43, jul.-dez. 2016, pp. 179-195.

PAZ, Otavio. Un sol más vivo. Org. Antonio Deltoro. Ciudad de Mexico: Era, 2009.

PIGNATARI, Décio. Semiótica e literatura. São Paulo: Perspectiva, 1974.

PROVASE, Lucius. Lastro, rastro e historicidades distorcidas: uma leitura dos anos 7o a partir de Galáxias. Tese (Doutorado em Teoria Literária e Literatura Comparada) - Faculdade de Filosofia, Letras e Ciências Humanas da Universidade de São Paulo, 2016.

SÜSSEKIND, Flora (org.). Apresentação. In: Corresponência de Cabral com Bandeira e Drummond. Rio de Janeiro: Nova Fronteira, 2001, pp. 7-17.

STERZI, Eduardo. O reino e o deserto. A inquietante medievalidade do moderno. In: Letteratura d'America, XXIX, n. 125, 2009, pp. 61-87.

TÁPIA, Marcelo. A nossa poesia francesa. In: ALMEIDA. Poetas de França. 5. ed. São Paulo: Babel, 2010[1936], pp. 5-8.

TOLENTINO, Bruno. O mundo como ideia. São Paulo: Globo, 2002.

ROBINSON-VALÉRY, Judtih. Préface. In: VALÉRY, Paul. Poèmes et petits poèmes abstraits. Présentation et choix de Judtih Robinson-Valéry. Paris: Gallimard, 2000.

VALÉRY, Paul. O cemitério marinho. Trad. Darcy Damasceno. Rio de Janeiro: Orfeu, 1949.

VALÉRY, Paul. Oeuvres I. Paris: Gallimard, 1957.

VALÉRY, Paul. O cemitério marinho. Trad. Darcy Damasceno. Salvador: Dinamene, 1960.

VALÉRY, Paul. O cemitério marinho. Trad. Edmundo Vasconcelos. São Paulo: Massao Ohno-Roswita Kempf, 1981(?).

VALÉRY, Paul. O cemitério marinho. Trad. Jorge Wanderley. São Paulo: Max Limonad, 1984[1974].

VALÉRY, Paul. Variedades. Trad. Maíza Martins Siqueira. São Paulo: Iluminuras, 1991.

WANDERLEY, Jorge. À margem do mar do cemitério. In: VALÉRY, Paul. O cemitério marinho. Trad. Jorge Wanderley. São Paulo: Max Limonad, 1984[1974], pp. 15-19.

ZULAR, Roberto. Valéry e o Brasil ou a literatura comparada como produção de contexto. Ponto e Vírgula, São Paulo, 2013, pp. 49-65. 


\section{AS MUITAS NATUREZAS DE “A PÍTIA”, DE PAUL VALÉRY}

A dinâmica que apresentamos da situação de Valéry traduzido no Brasil, atravessada tanto pelas traduções em livro de seus poemas, quanto pelo efeito de sua leitura na prática poética de diversos poetas brasileiros, acompanhou os mais de sete anos que nos dedicamos a traduzir pela primeira vez não apenas uma seleção de poemas de Charmes, mas uma versão integral do livro. Se, como vimos, a hesitação prolongada só se faz ato pela passagem de um plano a outro da composição, a consideração do livro como instância de enunciação possibilitou uma outra ordem de escolhas tradutórias.

A começar pelo título, optamos por um universo ontológico e etimológico que tentasse responder à composição de mundos que o conjunto dos poemas coloca em jogo, desde as determinações rítmicas, prosódicas, métricas e rímicas até os campos semânticos, os conceitos, as evocações e os questionamentos metafísicos dos modos de habitação da linguagem, que se desdobram no interior do próprio ato poético.

Assim, o nosso Charmes de Valéry se transformou em Feitiços, por uma série de razões que desenvolvemos no artigo "Traduzir os Charmes, de Paul Valéry", ${ }^{18}$ apontando para as forças que atuam sob as formas, para a transformação dos mundos que atravessam as palavras, para o gesto disruptivo do ato de encantamento em um mundo administrado, para o atravessamento de tempos e culturas que a poesia performa, sobretudo, quando traduzida; enfim, para a potência do ato poético.

Essa potência dos Feitiços começou a se delinear para nós durante a tradução de "A Pitia" que ao longo de todos esses anos ainda não havia sido traduzida em português. Não se tratava ali de uma simples referência à cultura clássica mediada pelo verniz simbólico de uma racionalidade francesa, mas de uma "inteligência em adultério", exercitando o corpo. Isto é, um poema que encena o transe da pitonisa recebendo os eflúvios da terra no próprio instante da transformação ritual da linguagem, quando corpo e palavra se determinam reciprocamente, quando, diz a Pítia, "as minhas/ duas naturezas vão se unir".

Essa linguagem saída da voz, santificada pelas forças mais impuras que funcionam lado a lado com os eflúvios da consciência (sem que nenhuma dessas instâncias se torne hierárquica), mais do que uma

18 Cf.: Faleiros, A.; Zular, R. Traduzir os Charmes, de Paul Valéry. Domínios de Lingu@gem, v. 11, 2017 , p. 1.536 . 
metalinguagem é uma outra forma de habitação da linguagem, um outro modo de existência, um limiar entre as muitas naturezas de que somos feitos. Uma outra voz que sabe "quando soa também/ não ser mais a voz de ninguém/ sendo a das ondas e dos bosques".

Por se tratar de uma tradução a quatro mãos, percebemos o quanto levar ao limite o atravessamento de corpos, planos, possibilidades e tempos no interior do nosso próprio processo tornava-se não só um aparato crítico, mas uma operação tradutória. Mas como sabia Valéry, a literatura só existe como ato, e é na abertura dessa operação para outros corpos, outros tempos e outras camadas de leitura que saberemos o seu alcance, quem sabe para possibilitar outras e infinitas retraduções. 


\section{A Pítia}

a Pierre Louÿs

"Hæc effata silet; pallor simul occupat ora”. (VIRGÍlLIO, Æn., IV)

A Pítia, exalando as chamas

Pelas ventas duras de incenso

Ofegante, ébria, berra!... As ancas

Mugindo! A alma em horror intenso!

Pálida e a fundo mordida,

Com a pupila suspendida

No mais alto ponto do horror,

O olhar de sua máscara ausente

Do vaso arranca-se vivente,

Pela fumaça, com furor!

No muro, seu demente vulto

Onde reina um demônio maior,

Por entre o fétido tumulto

Vê-se um fantasma nadador,

Ele num transe tremendo

O prumo da sala rompendo,

Se a doida demora em seu urro,

Imita escuros entusiasmos,

Apressa os deuses e os espasmos

A se acabarem no futuro! 
Essa mártir suando gelada,

Dedo sobre dedo desdobra, Vociferando entre as patadas

De um tripé que estrangula a cobra:

"Maldita! Com o mal sofro mesmo!

Minha natureza é um abismo!

E aberta aos espíritos! Grita!

Perdi o meu próprio mistério!..."

Inteligência em adultério

Compreende um corpo que exercita!

Dom cruel! Mestre imundo, para

Rápido, ó divino fermento,

De fingir estar prenhe de nada,

No puro ventre sem amante!

Acabe com esta horrível cena!

Veja em meu corpo a curva obscena

Terna a romper-se para flechar,

Como seu traço detestável,

No céu, a alma implacável

Que em mim já não posso guardar! 
Quem me fala, em meu próprio lugar?

Que eco me diz: "É mentira?"

Quem me ilumina?... Me calunia?

E quem, dos verbos a espumar,

Raios racham a língua minha,

A faz dizer sua ladainha

Rompendo os cabelos então

Baba e masca e a desordem faz ver

De uma boca que quer se morder

E retomar a confissão?

Deus! Não conheço outros crimes

Apenas o de ter vivido!...

Se como vítima me intimes

E no altar de um corpo vencido

Se curvas um monstro, se matas

Esse monstro, e a besta que abates;

A cabeça do corpo reparte

Pelas crinas desde a têmpora,

Que esta mais pálida lâmpada

Encha de mármores a noite! 
Então, por esta vagabunda

Morta, errante, e lua infinita,

Seja o mar surpreendido, e a onda

A eternos cumes submetida!

O humano em estátua se transmuda,

Peito de pedra, a alma muda,

E pelos vidros de meu olho,

Possa um povo e suas linguagens

Fixar-se num povo de imagens

Mudo de bobagem e orgulho!

Ei! Eu!... Virar a viperina

Cujo impulso de emoção

Flagra a carne que desatina

Seus retalhos em profusão!...

Retoma o insensato combate!...

Teu pensamento em disparate

Vai à esquiva alegria, e revém,

Ó memória, a esta magia

Que só drena sua energia

Dos teus arcanos, não de outrem! 
Meu caro corpo... Forma amada, Frescor pelo qual Afrodite

Não foi nunca desalterada, Terno cume, intocada noite, E essas partilhas indizíveis

De uma argila em ilhas sensíveis, Doce matéria de minha sorte, E que aliança nos arrumas, Antes que o dom dessas espumas, Faça de ti um corpo à morte!

Em ti, meu ombro, o ouro exposto Desde uma fonte de negrura, Que nunca encontres o meu rosto Fundido na mesma doçura!

Soerguidas às minhas narinas Abrem-se às distâncias marinhas As mãos cheias de seios intensos, Em meus braços de belas alças Meu abismo bebeu as imensas Profundezas que o vento enlaça! 
Que pena! oh rosas, toda lira

Contém uma modulação!

Na noite triste que delira

Surgiu uma constelação!

O templo torna-se um antro,

E a tormenta dos sonhos entra

Nos céus que já foram tão belos!

É preciso gemer, se alçar

A não sei que êxtase, e abraçar

Com um resto os meus cabelos!

Me viram com as marcas roxas, Que minha pobre pele espelha;

E me embeberam em aromas

Suaves como lã de ovelha;

Como amuleto vivo tocavam

Minha garganta que arfava

Sob os ornatos de peçonhas,

Tonta, bêbada de epireumas,

Sob o murmúrio de uns neumas

Me deram honras subterrâneas. 
O que fiz para estar em desgraça

Pura, nesses horríveis ritos?

De um asno a sombria carcaça

Serviu aos deuses de abrigo!

Mas uma virgem consagrada,

Tal concha nova e nacarada

Só deve àquela divindade

O sacrifício e o silêncio,

E esta íntima violência

De que é feita a virgindade!

Por que, Potência Criadora, Que fez o mistério animal, Nesta virgem fundadora, Plantar maravilhas do mal!

Com estes dons que me outorgas?

Crês, quando se rompem as cordas, Que vai jorrar mais belo o som? Teu plectro vibrou em meu torso Mas só lhe concedes a força De soar como um caixão! 
Sê sem oráculos, tem piedade! E com tuas mãos deslumbrantes Transforma em carícia o milagre, Retém sobre-humanos instantes! Em vão é que tu comunicas Aos nossos tênues talos, únicas Comoções de tua clareza! A água calma é mais transparente Que a tempestade, esta parente De uma confusa profundeza!

Lá vai a luz, a luz divina, Não é ela um terrível raio

Que nos precede e adivinha Como um sonho cruel e claro!

Que estoura!... E vai nos instruir!... Não!... Solidão vem só luzir Na chaga de ares imensos Onde nenhuma arquitetura, Mas só a rascante ruptura Nos impõe seus puros desertos! 
Não tirem, mãos universais,

De meu rosto tempestuoso

Umas centelhas magistrais!

Acasos jogam o mesmo jogo!

O porvir do passado é irmão

E no inverso de sua feição

Há um semblante empalidecido

Que só vê desde sua vidência

Uma mesma feroz ausência

De ilhas mais belas que o olvido.

Negras testemunhas das luzes

Não busquem mais... Chorem, olhos meus!

Choros cujas primeiras fontes

São profundas demais nos céus!

Não há demanda tão amarga!...

Porém a pupila mais larga

Das trevas vai se prover!...

Deixando a raça apavorada,

A distância desesperada

Nos deixa o tempo de morrer! 
Minha alma, escuta o rio fluindo!

Aqui quais são as cavernas?

Será meu sangue?... Ali vem vindo

Um rumor de ondas severas?

De meus segredos soam auroras!

Tristes metais, fontes sonoras,

O que dirão desse porvir!

Matem a hora que se avizinha, Rebatam numa rocha... As minhas

Duas naturezas vão se unir!

Mas que formidável subida!

Que degraus terríveis e altos!

Eu sinto na árvore da vida

A morte subir de meus saltos!

Ao longo dessa linha fria

O dedo daquela que fia

Entrança sua atroz vontade!

E soluçando a crise irrompe,

Até minha nuca onde rompe

Uma alta voluptuosidade! 
Ah! Quebra os mais vivos portões!

Faz rachar as inúteis trancas

Espesso rebanho de espantos,

Arrepiado de cintilações!

De currais fúnebres surgindo

Minhas trevas vão te nutrindo

De fabulosa profusão!

Salta, de sonhos saciada,

Ó horda espinhosa e crispada,

E se esfuma no ouro, Tosão!

*

Cada vez mais atormentada

Desatina, estertora, avermelha

A profetiza fomentada

Pelos sopros do ouro vermelho.

E enfim o céu se manifesta!

A orelha do prelado em festa

Se aventura rumo ao futuro:

Se curva numa espera santa

Pois uma voz tão nova e branca,

Escapa desse corpo impuro: 
Situação de Valéry traduzido no Brasil - 682

Honra os Homens, Santa LINGUAGEM, Fala profética e ornada,

Bela corrente e em sua engrenagem

O deus na carne desviada, Generosidade, epifania!

Aqui fala uma Sabedoria

E soa esta Voz entre vozes,

Que sabe quando soa também

Não ser mais a voz de ninguém

Como a das ondas e dos bosques!

Tradução:

Ávaro Faleiros e Roberto Zular 